Illinois State University

ISU ReD: Research and eData

Theses and Dissertations

$4-14-2014$

\title{
This wall speaks: graffiti and the location of transnational space Palestine
}

Ashley Toenjes

Illinois State University, ashley.toenjes@gmail.com

Follow this and additional works at: https://ir.library.illinoisstate.edu/etd

Part of the Near Eastern Languages and Societies Commons, Other International and Area Studies Commons, and the Political Science Commons

\section{Recommended Citation}

Toenjes, Ashley, "This wall speaks: graffiti and the location of transnational space Palestine" (2014). Theses and Dissertations. 132.

https://ir.library.illinoisstate.edu/etd/132

This Thesis is brought to you for free and open access by ISU ReD: Research and eData. It has been accepted for inclusion in Theses and Dissertations by an authorized administrator of ISU ReD: Research and eData. For more information, please contact ISUReD@ilstu.edu. 
THIS WALL SPEAKS: GRAFFITI AND THE

LOCATION OF TRANSNATIONAL

SPACE IN PALESTINE

\begin{abstract}
Ashley Toenjes
\end{abstract}
84 Pages

May 2014

Extant literature on the Palestinian-Israeli separation wall privileges the wall's function in border-making, while ignoring other discursive and spatial functions it fulfills. My paper reaches beyond the border-making function of the wall, resituating it as a node among different spatial networks of activism and tourism. This thesis argues that Palestinian tactical use of graffiti on the separation wall traverses these spatial networks and provides a case for us to consider graffiti not only as a process which links these networks, but also as a discursive tool through which Palestinians appeal to transnational actors, particularly those who are complicit with and invested in the Israeli occupation of Palestine. A historical analysis of graffiti in Palestine reveals the ways political messages have changed from localized, national contexts (Peteet 1996) to what I argue are transnational messages which link up to the different transnational networks that are centered on the wall.

Drawing on De Certeau's (1988) concepts of strategy and tactic, this thesis explores how transnational space is socially constructed around the wall. This dyad will 
be used to identify the wall as an Israeli strategy of controlling both Israeli and Palestinian space, while Palestinian resistance to and graffiti of the wall are examples of tactic. Sassen (2001), Castells (2012), and Fraser (2008) emphasize the importance of communications technologies in creating transnational networks and space. The ways in which images of the graffiti circulate in a transnational arena, especially through the use of internet, indicate the role of communications technologies, but decenters their importance in favor of the materiality of the wall and the networks that converge in it. 
THIS WALL SPEAKS: GRAFFITI AND THE

LOCATION OF TRANSNATIONAL

SPACE IN PALESTINE

ASHLEY TOENJES

A Thesis Submitted in Partial Fulfillment of the Requirements

for the Degree of

MASTER OF ARTS

Department of Politics and Government

ILLINOIS STATE UNIVERSITY

2014 
THIS WALL SPEAKS: GRAFFITI AND THE

\section{LOCATION OF TRANSNATIONAL}

SPACE IN PALESTINE

ASHLEY TOENJES

COMMITTEE MEMBERS:

Kam Shapiro, Chair

Yusuf Sarfati

Issam Nassar 


\section{CONTENTS}

$\begin{array}{ll}\text { CONTENTS } & \text { i }\end{array}$

\section{CHAPTER}

I. INTRODUCTION 1

Organization of Thesis $\quad 6$

References 9

II. THEORETICAL AND HISTORICAL CONTEXTS 10

Introduction $\quad 10$

Networks and the Transnational 10

A Transnational Place? 13

Translocality and Tourism 16

Transnational Activism $\quad 19$

Space and Inequality $\quad 20$

References 24

$\begin{array}{ll}\text { III. TRANSNATIONAL PALESTINE } & 25\end{array}$

Introduction $\quad 25$

A Bi-National Wall? $\quad 27$

Occupation as Spatial Practice $\quad 28$

What's in a Name? $\quad 30$

Spaces of Separation $\quad 34$

A Wall that Connects 39

Tourism Networks $\quad 42$

Conclusion 46

References $\quad 47$ 
IV. GRAFFITI AND THE APARTHEID WALL 50

Introduction $\quad 50$

Issue Framing $\quad 53$

Graffiti Locations $\quad 56$

$\begin{array}{ll}\text { Graffiti Themes } & 58\end{array}$

Christian Themes $\quad 59$

Transnational Politics $\quad 62$

Whose Transnational Wall? 65

$\begin{array}{ll}\text { References } & 72\end{array}$

$\begin{array}{ll}\text { V. CONCLUSION } & 73\end{array}$

$\begin{array}{lll}\text { APPENDIX A: } & \text { Maps } & 77\end{array}$

APPENDIX B: $\quad$ Historical Images of Graffiti in Palestine 79

APPENDIX C: $\quad$ Contemporary Images of Apartheid Wall Graffiti 82 


\section{CHAPTER I}

\section{INTRODUCTION}

Zionist colonization, even the most restricted, must either be terminated or carried out in defiance of the will of the native population. This colonization can, therefore, continue and develop only under the protection of a force independent of the local population - an iron wall which the native population cannot break through. This is, in toto [sic], our policy towards the Arabs. To formulate it any other way would only be hypocrisy (Jabotinsky 1923).

In 2002, as part of its military occupation of Palestine, the Israeli government began construction of an 8 meters high concrete barrier which would come to surround and cut through much of the West Bank of Palestine. Though concrete was selected in favor of iron, nearly eighty years after writing, Vladimir Jabotinsky's crude blueprint for the colonization of Palestine was realized. Jabotinsky's ideas formed the basis of revisionist Zionism, a brand of European Jewish nationalism that was most uncompromising in its views of how to treat indigenous Palestinians in the colonization of Palestine and in negotiating with the British, who were in control of Palestine at the time of Jabotinsky's writing (Smith 2012, 122-3). As evidenced in the quotation above, Jabotinsky and his followers believed that nothing short of literal and physical separation would be safe for Zionist colonists, and though Israeli strategies of occupation often created de facto separation of Palestinians and Israelis, the construction of the Wall in 2002 was the first time the Israeli government enacted steps to literally separate Palestinians and Israelis. 
Of course, the separation of Palestinians and Israelis is, for the time being artificial. The land which is now the Palestinian West Bank and Gaza Strip and Israel, was historically inhabited by Palestinians. In 1948, the British ended their 28 year mandatory rule over Palestine and handed the land over to the Zionists. A war between the Zionists and neighboring Arab countries broke out, with Egypt claiming a piece of land on the sea which became known as the Gaza Strip, and Jordan claiming a larger piece of land to the east, which is now known as the West Bank (it is the western bank of the Jordan River). In 1967, another war broke out between Israel and neighboring Arab states when Israel attacked Egypt. In this war, Israeli won the Gaza Strip and West Bank from Egypt and Jordan, thus began the Israeli occupation of Palestine. The idea behind total separation between Palestinians and Israelis is artificial because while the West Bank and Gaza Strip remain Palestinian Arab, except where settlements encroach, the land of what became Israel, was never totally cleansed of its indigenous, Arab population. So, no matter the efforts of Israel to build a Wall around the Palestinian West Bank, there will continue to be Palestinians living in Israel.

This thesis is concerned with how Palestinians living within the West Bank of Palestine connect with the transnational. As later chapters discuss, decades of dedevelopment has left Palestine with impaired abilities to create the technologies used to connect to a global world. In cases where those technologies are developed, they are very expensive, and are disproportionately available to urban, upper middle-class Palestinians. Theories of the transnational argue that communications technologies are the link that connect the transnational, but can Palestinians who do not have access to such technologies connect to the transnational in other ways? This is the guiding question of 
this thesis.

If it is true that communications technologies are the link that connects the transnational (Castells 2012, Sassen 2006), how do people without access to those technologies connect? One possibility is finding mediated access. Through the following case study of the Apartheid Wall in Palestine, I argue that spaces in Palestine which attract international actors can be used by Palestinian actors to access transnational spaces and networks. The case study focuses on the spaces the Wall produces, and analyzes how graffiti is used as a tool by Palestinians and others to communicate messages from within Palestine to transnational audiences.

To contextualize the processes set out above, it is important to note some limits in current scholarship on Palestine and Israel. Though there are many different ways that studies on the people, land, and nations of historic Palestine are framed, until recent years, none provided a transnational context for this field of study. Articulating the importance of transnational perspectives in the study of the Israeli occupation of Palestine is one of the key points of this thesis. Before making that case, I briefly consider some of the dominant approaches to studies on Palestine/Israel.

Works on Palestine and Israel are often limited to a nation-state perspective, where problems are framed in terms of Palestinian or Israeli right to land (Jung 2004), and actions that are or are not justified in defense of land. When we consider that Palestine, a nation without a state, and with increasingly less territory in the face of Israeli expansionism, and Israel, a nation with a state but ambiguously, yet expanding, territorial markers, who sees its nation-statehood constantly challenged by Palestine, it is not surprising that academics are still concerned with yet-to-be completed nation- 
statehood for both Israelis and Palestinians (prominent works which follow this methodological nationalism include Smith 2012, Khalidi 2007, Shafir 1996). While this bi-national framing lends important insights to the perspectives of the two major players in the Israeli occupation of Palestine, it misses other important processes, dynamics, and actors, and especially those that are international.

Jung identifies three other analytical frames that are commonly used to assess the occupation of Palestine- Islamic/Jewish, Arab/Israeli, and colonial/Western imperialism (Jung 2004, 14-15). These frames are useful in capturing elements of what the Palestinian/Israeli lens misses, and I will dwell for a moment on the transnational elements, parsing what it useful and critically dismissing other aspects. Each of these frames identifies possibilities for a transnational framing of Palestine, but they do so in ways that diminish other important aspects of the occupation.

The Islamic/Jewish framing locates the religious importance of the land of historic Palestine in a Muslim context, and suggests that Muslims and Islamic governments may have a moral investment in supporting Palestine and Palestinians (Jung 2004, 14). The inverse of this, which Jung notably does not state, is that Jews outside of Israel would also have ethno-religious affinities toward supporting Israel. Though there are certainly linkages in world Muslim and Jewish communities that align with this kind of simplistic identity politics, religious framing papers over too many of the complexities of the occupation. Despite the international and transnational dimensions of this approach, it erases the colonial and political nature of the occupation, the interfaith peace work Muslims and Jews are doing together, and the identities of Palestinian Jews, Christians, and secularists. This religious framing provides a narrow and seriously distorted 
perspective of the realities of the occupation and as such does not present a meaningful transnational lens.

The Arab/Israeli dimension highlights regional tensions, and centers on the ideology of freeing Arab lands from occupation, a popular theme in mid-to-late twentieth century Arab politics. Palestine was often the poster child of such movements, and this can be seen in Nasser's Egypt, the al-Assads' Syria, Hussein's Iraq, and Gadaffi's Libya (Collins 2011). This frame overlaps with the final frame Jung identifies, that of colonialism/Western imperialism. This mode of framing the occupation locates Zionism, and later Israel, as dependent on British support in the early twentieth century, and "almost unconditional" US support since the 1960s (Jung 2004, 15). Others agree that without British military, economic, and political backing, the Zionists would not have achieved their national goals in 1948. Israel won later wars in 1967 and 1973 again with the military backing of a great power, this time the US (Smith 2012, Collins 2011, 5). The current occupation and its practices are supported by millions of dollars of US and EU foreign and military aid to Israel (Coren and Feldman 2013, Sharp 2013, Collins 2011). As the graffiti analysis in the fourth chapter argues, this frame is an important one in considering the transnationalization of Palestine (and its occupation), because Palestinians use it appeal to Americans and Europeans to be accountable for their governments.

The Arab/Israeli and colonialism/Western imperialism frames provide a solid starting point for beginning to think about Palestine in a transnational context. However, two inter-related problems emerge from the frames as Jung identifies them. First, they are rooted in a state centered approach. Following from that, the top-down perspective has 
the effect of overlooking the non-formal actions of Palestinians. Given the statelessness of Palestinians, this effect is particularly important.

\section{Organization of Thesis}

One thread of argument woven throughout this thesis is that current debates on the contemporary transnational are insufficient for theorizing how communities without access to communications technologies participate in transnational spheres. Prominent thinkers on the topic focus on the role of communications technologies, but do not provide insights as to how mediated access might occur. By reading network theory through the lens of spatial practice, chapter one opens the way for considerations on mediated access. When networks are considered in dialogue with the spaces they function in, as both creators of space and created by space, networks are situated with a spatial intermediary. Built environments, or the physical structures we interact with on a daily basis, including homes, buildings, and business plazas, are an important element in shaping human spatial interaction. Drawing on Harvey's (2000) and De Certeau's (1988) work, I argue that built environments produce, and are used to produce spaces of inequality. De Certeau's discussion of the power dynamics created by built environments include the development of an important conceptual dyad in this thesis, that of tactic and strategy. Strategy is the calculated, coordinated plans of those in power to maintain a status quo, and is enacted through the production and imposition of space which protects and reinforces power inequalities. Those who are othered by the status quo are left with tactics, uncoordinated actions that do not obey the laws of place and seek to manipulate or divert space (De Certeau 1988, 30). Chapter two sets the stage to discuss the 
possibilities of how people without regular access to communications technologies may tactically divert the spaces they operate in to access networks with access to communications technologies.

Working past the bi-national and state-centered frames critiqued above, chapter three recasts Palestine as a transnational space. This is important because it uncovers transnational networks that have been active in Palestine, some for decades and others for centuries. Historically these networks included sites of commerce and pilgrimage, as well as those networks which gave rise to Zionist immigration in the late nineteenth century, and later British and US support for the Zionist project in Palestine. After reconstructing the history of Palestine-Israel as one with deep inter- and transnational networks, this thesis will map out some of those networks in the present day. In particular, networks of Christian religious tourists and anti-occupation activists are traced. Transnational activist networks are considered against the perceived influence of current networks in the US and EU that act in support of Israeli occupational practices. Once we have centered some of these transnational connections, we can look to how they respond to spatial practices of the occupation. For example, how do the spaces around the Wall impact tourist and activist networks that predate the Wall? And, in turn, how do those networks change and inform those same spaces? Finally, how do Palestinians interact with those spaces and networks? By fleshing out some of these processes, we will see how Palestinians are able to tactically interact with networks and space, especially through the use of graffiti on the Apartheid Wall.

In the fourth chapter, I look to analyses of graffiti on the Apartheid Wall to argue that Palestinians and others tactically use the space and networks surrounding the 
Apartheid Wall to reach transnational communities. That the space and its networks are connected to the transnational makes the space surrounding the Wall transnational space. The Wall is transnationalized in several processes, including the frequent presence of international actors at the wall, as well as the transnational circulation of images of the Wall and its graffiti, often done by transnational actors through their access to communications technologies. Historical analyses of graffiti in Palestine reveal that Palestinians tactically used graffiti in the first Intifada, or nationalist uprising, to create national linkages in the absence of national institutions such as state media or state education (Peteet 1996, Oliver and Steinberg 1990). The presence of such nationalist graffiti on the walls of refugee camps and other places that do not entertain tourists, contrasted with the overwhelming presence of outwardly focused, transnational messages on the Apartheid Wall, point toward the tactical use of space to divert it from its intended purpose of separation, and create new meanings and linkages which challenge the structures of the occupation. An important part of theme of this chapter is drawing out the ways that messages are directed toward the transnational actors who share the place of the messages. 


\section{References}

Castells, M. (2012). Networks of outrage and hope: social movements in the Internet age Cambridge, UK: Polity.

Certeau, M. de. (1988, c1984). The practice of everyday life. Berkeley: University of California Press.

Collins, J. (2011) Global Palestine. New York: Columbia University Press.

Jabotinsky, V. (1923) The iron wall.

Khalidi, Rashid. (2006) The iron cage: the story of the Palestinian struggle for statehood Boston : Beacon Press.

Sassen, S. (2006). Territory, authority, rights: from medieval to global assemblages. Princeton, N.J.: Princeton University Press.

Smith, C. D. (2010). Palestine and the Arab-Israeli conflict. Boston: Bedford/St. Martin's. 


\section{CHAPTER II}

\section{THEORETICAL AND HISTORICAL CONTEXTS}

\section{Introduction}

This chapter introduces theoretical considerations on the transnational, networks, and space, while offering insights on the ways they are related to one another. Theorists of the transnational agree that the transnational is constituted through networks, and that the transnational itself is mostly a formless, abstract, thing. In other words, by accessing part of a network, one is able to access the transnational. A second thread of this chapter identifies the relationship between tourist and activist networks and space. In this section I show how space is comprised of overlapping networks and how those networks adapt to and influence the spaces they encounter. A final piece of this chapter turns to discussions of Harvey and De Certeau to argue that interactions with space are influenced by built environments. The power dimensions that result from this spatial interaction, and especially De Certeau's conceptual tools for understanding those power dimensions, are considered in detail as they are employed in later chapters.

Networks and the Transnational

Sassen, Castells, and Keck \& Sikkink agree that networks bound by communication flows are a critical part of locating the transnational. In Territory, 
authority, rights: from medieval to global assemblages (2006) and The global city: New York, London, Tokyo, (2001 [1991]) Sassen argues that urban centers and the flow of capital create the need for networks to assist cities in their economic and global growth. These "global cities" become such when they are the site of numerous networks, and they are transnationalized through those networks which are sustained especially by communications technologies. In Activists beyond borders: advocacy networks in international politics (1998), Keck \& Sikkink agree with Sassen's diagnosis of the network as the vein which connects different sites of the transnational, but Keck \& Sikkink focus on non-state actors and NGOs which get connected through networks rather than global cities. Whereas Sassen and Keck \& Sikkink argue that networks of communications flows connect the transnational, Castells argues that networks and their communications technologies are themselves the site of the transnational. In his case studies, Castells looks at how different networks centered on capital, government, and public space are connected through communications, and he identifies key processes that happen within those networks. Castells outlines this argument in Communication power (2009) and reconsiders it in light of a global wave of protest and social movements in Networks of outrage and hope (2012).

Sassen says that the transnational is a collection of networks that connect different combinations of global cities in different ways. Cities become transnationalized when networks of cities form around a common concern. In Sassen's work, these concerns are related to the management of global capital, where a collection of global cities will be linked through monetary, legal, and other concerns related to a particular industry. Conversely, any global city is situated upon a collection of intersecting networks. The 
transnational can take human or physical form in fleeting "territorial moments", but it is sustained in these networks, which are connected through technological communications (2008, 2007). Technological communications are important because they are what connect localized struggles to cross border networks $(2007,83)$ and they have been an important tool in helping nonformal political actors connect. This process of connecting has also rendered visible actors who were previously invisible to the state $(2006,90)$.

Castells is also concerned with the role of technological communications in creating a global civil society (2008). One dynamic which Castells identifies is how technological communications have facilitated the flow of public opinion. This process deemphasizes a global civil society's reliance on political institutions and mass media-an important concept in the development of transnational space in a non-state such as Palestine, which has very weak political institutions $(2008,86)$. Castells maintains that media still plays a significant role in global publics, arguing that the public sphere has shifted from being organized around national institutions and territorially bound societies to being organized around the media. Transnational publics now rely on a "global/local communication media system" $(2008,89)$.

Sassen and Castells, as well as Fraser (2009) emphasize the role of communications technologies in the construction transnational space. If those technologies are a prerequisite of participating in the transnational, do those with limited or no access to communications technologies participate in the transnational, and if so, how? The case of Palestine provides at least one example that shows the need for decentering the role of communications technologies in theorizing the transnational. 


\section{A Transnational Place?}

To consider the above questions, we need to take up the relationship between place and space. By shifting the lens from network to place, we can also uncover the political nature of place, and begin to understand the different processes that converge to create spaces in a place (Yaeger 1996, 5). Sassen (2008) argues that the transnational is comprised of places which are linked by networks. Past studies which have focused on the ways those networks function, miss the functions of the transnational and its "territorial moments", or the times when networks take physical form, embodied in a person, building, or other object that acts as a node within the network. Although Sassen argues that territorial moments are fleeting, the new model presented below suggests that networks can be rooted in place. By shifting the focus to place, and instead uncovering which networks and process converge there, we can better understand how the transnational takes shape, and include local actors, including those who are resource poor or immobile $(2008,82-3)$.

Sassen's important theoretical insights of the place-based transnational do not delink the transnational from its location in a network of global cities connected through transnational flows of capital. Sassen emphasizes the role of place, but as a way of understanding localized, place to place connections. Such connections defy a scalar, or hierarchical understanding of transnational organization, where one must pass from city to nation to get to the transnational. Rather, cities can connect to other cities directly, particularly through the use of communications technologies. Sassen concludes from this that local actors, including the resource poor or immobile, are able to connect, create transnational linkages, or be part of the transnational in other ways (2008). 
There are two lines of critique to draw out in Sassen's argument. One is her articulation of a place-based transnational and the other is in her assumptions about communications technologies. Sassen's place-based approach still locates a place as one of many nodes which make up a network. In other words, the network is built from many places. I suggest a model that inverts the relationship Sassen accords to the network and place, one which considers a place as the convergence of many networks. This inverted model has important implications, particularly when we consider the relationship between spatial practice and networks. That relationship also relates to the critique of communications technologies.

Despite Sassen's claim that communications technologies are the means through which localized nodes of networks connect, the problem with this assumption is that "the resource poor and immobile" whom Sassen attempts to write into theories of the transnational, do not always have access to communications technologies $(2008,82)$. If we use Sassen's approach to the network, places ought to have access, communicative or otherwise, to other places in order to link to the transnational. Without that access, people and places, Sassen seemingly suggests, are not equipped to be part of the transnational. By reconsidering access to the transnational through a place where transnational networks converge, we create a theoretical perspective which uncovers how local place and local actors with limited access to communications technologies can participate in the transnational.

The model of transnational space for which I argue does not dismiss the role of or need for communications technologies in connecting networks and space, but rather suggests a framework which decenters its importance. In this place-based model, the 
place is the meeting-point of different networks and those networks are important in transmitting information from the place. Communications technologies are likely part of that process, but how does information get to the place? Are there local processes that bring information to the nexus of networks independent of communications technologies? And what about when those processes exist in part because access to communications technologies is so limited? That possibility would indicate that communications technologies are not always the central factor in linking networks, but rather, themselves an extension of a place-based transnational.

So far, I have discussed a model which indicates the formation of space around a place that acts as a hub for different networks. In this consideration, a place becomes important because of the convergence of networks in it. A second, but no less important process happens where these networks converge. They create, influence, and change spatial practice. Consider a circuit breaker in a house. It is significant because it brings all of the electrical work together in a meaningful way. Because of that important function, it has an impact on the ways in which a resident interacts with her home. For example, she is likely to know where it is (as opposed to the rest of the wiring in the home), she is not likely to hang a coat hook or mirror on that part of the wall, and the well-prepared resident may keep a flashlight nearby in case a fuse blows. Each of these actions, or in-actions, is influenced by the circuit breaker's role in bringing together all of the wiring that corresponds to a house. If the wiring did not centralize in a place, the person may respond to the circuit breaker and wiring in her home very differently. When networks form around a physical place, people respond to networks and the place differently than if they were not entwined. 


\section{Translocality and Tourism}

What draws networks to converge in a particular place? Our lens is transnational so we can think about reasons in which people, ideas, and goods move transnationally. Appadurai's concept of translocality (1996) suggests some ways this discussion can be shaped. Translocalities are places which are detached from national contexts $(1996,44)$, where the detachment stems from the translocal place's submission to global or regional processes. Appadurai further defines translocal by way of example, including corporatized cities (Sassen's global city), border zones, tourist zones, and parts of the city inhabited by economic and political migrants (Appadurai 1996, 44).

Appadurai suggests that tourist zones are translocal because of the local changes which are made to attract transnational tourists. For example, Sri Lanka's emphasis on Caribbean-style resorts in some places are sharply contrasted by Buddhist-nationalist projects in others $(1996,48)$. There are at least two important extensions of Appadurai's account of tourism that contribute to the creation of translocalized spaces. The first is cosmopolitan actors, who bring their own imagined context to a place, and how they interact with each other and with "locals". The second process is how networks of tourism are expanded upon when tourists share stories and images of their travels.

Liechty's case study of Kathmandu as a translocal place brings to light the ways imagined contexts both inform cosmopolitan actor's expectations of a place and how local actors respond to those imagined contexts (1996). Liechty identifies three types of tourism that are prominent in Kathmandu: hippie tourism, adventure tourism, and consumer tourism. The hippie tourists come to Kathmandu seeking cheap drugs and accommodations, adventure tourists seek commodified authenticity of their orientalist 
imaginings (read: cheap tourist mementos). Whereas these two classes of tourists often originate in Euro-America, consumer tourists tend to be middle and upper-class Indians seeking imported European and East Asian goods and fine dining, at relatively cheaper costs than in India. Each of these groups of tourists seek a competing version of Kathmandu, and according to Liechty, rarely cross paths in the city $(1996,112)$. The apparent boundaries for the different types of tourists seems to informed, in part, by the tourists active seeking out of the Kathmandu that they imagine, but those different Kathmandus are also created by Nepali business people. Drugs are made available in certain neighborhoods, while drugs and people who look "hippie" are barred from others. Natural foods and outdoor hiking equipment are marketed to adventure tourists, while upscale, but price controlled goods lure consumer tourists into other areas $(1996,107-$ 111). I recount Liechty's work at length because it provides a vivid account of tourism's connection of external actors with internal actors, and of tourists with "locals". Additionally, it indicates the various relationships created by different spaces that overlap in the same place. Liechty's account casts Nepali business owners as reactionary, as simply supplying the demands of different kinds of tourism, but this account glosses over the most important aspect of this tourist network, which is the dialectic relationship between tourists seeking their imagined Kathmandu, and Nepali business owners creating imagined Kathmandus.

The second extension that I add to Appadurai's account of tourism and translocality is the expansion of tourist networks when tourists share accounts of their travels. It is within this extension that I see Nepali business owners not only as merchants supplying a tourist generated demand, but also as integral players in the shaping of 
imagined Kathmandus. When people travel, they take from the places they visit memories, photos, video, souvenirs, and stories. Liechty gives an account of adventure tourists seeking "ethnic" clothing to purchase, as part of phenomenon he calls "going native" $(1996,109)$. The effort of Nepali business owners to make these and other elements of the tourists' imagined "authenticity" of local culture available not only fills the orientalist demand for such goods, but it also provides those tourists a tool to share an extension of their imagined Kathmandu with others at home. By providing those tools and props to tourists, Kathmandu business owners are an active part of the processes which create the imagined Kathmandu in the first place. In other words, people who have never been to Kathmandu but hear others' experiences of it, see others' photos of it, or receive souvenirs from imagined Kathmandus, are also part of a tourist network that becomes reterritorialized in Kathmandu. When we think about this process in an age of technological advance, we can also think about how communications technologies fill in this story, where people can blog or share images on social media, quickly reaching expansive audiences.

As summarized above, Sassen argues that global cities are composed of multiple, overlapping network hubs. In the Kathmandu example, we saw several networks form in the same place around tourist imaginings. Sassen identifies how networks overlap to make global cities, but by considering how networks overlap to create tourist places, such as the example of Kathmandu, we see how space beyond a global city can be similarly constructed upon a convergence of networks. The following section discusses how networks of transnational activism converge. 
Transnational Activism

Fraser (2009), Tarrow (2002), and Keck and Sikkink (1998) remind us that socialactivist networks connect transnationally, and provide cases of place-based, translocal importance. Fraser and Tarrow both discuss cases of anti-WTO movements and organizations to challenge the politics of restructuring. Tarrow's focus on the 1999 Seattle protests of the WTO provides an example of a temporally limited place of network convergence. Contested borders, war zones, and sites of human rights abuses often attract the attention of international monitors, relief agencies, and news agencies. Here, I am thinking of the US Central Command building that was located on the outskirts of Baghdad shortly after the 2003 US invasion of Iraq. All international news agencies that reported on the invasion were headquartered in this building, making the Central Command a hub of international reporting.

Each of these catalysts for network convergence creates different social circumstances in which people will respond to the place of convergence. People in Seattle will likely respond very differently to WTO protestors than the people of Cancun will respond to the floods of American and European tourists who occupy their beaches. Of course, it is not just the place and motives around which the networks converge that will shape responses, but also the relationships which those near a place, the locals of Seattle or Cancun, for example, have with the place and with the networks. In the case of contested borders, those seeking redress may try to draw international attention to the ways the border conflict challenges their daily life, while those benefitting from the conflict may try to detract attention or challenge unflattering press.

If we consider a society where access to communications technologies is 
controlled, but there are places where transnational networks are active in transmitting information to and from a place, we might consider how members of that society would seek access to the transnational networks and their place of convergence. This model may apply in different contexts, and there are different combinations of factors which might limit one's access to communications technologies. We could find this barrier in societies that have resisted technological modernity, in rural communities, or in places in which unequal resource distribution creates inequalities in access to otherwise present communications technologies (such as inner-city America). It is the third of these options which is of interest to this thesis. By putting Harvey and De Certeau in dialogue with each other, the influence of power structures over the creation of space, and human interaction with that space become evident.

\section{Space and Inequality}

Many writing about "space" agree that the meanings of space are socially constructed and socially contested. Harvey reminds us of Marx's insight that the difference between a honeycomb and human architecture is that human architecture exists in the imagination before it takes physical form (Harvey 2000, 159). Harvey (2000), De Certeau (1988), Yaeger (1996), and Sassen (1996) each build on Marx's observation, agreeing not only that the built environment is a social production, but also that it creates unequal social relationships which seek to reproduce themselves. Yaeger identifies "economic asymmetries" and "naturalized hierarchies" as two vehicles through which inequalities are reproduced in space, and hegemony established and maintained $(1996,8)$. Harvey, De Certeau, and Sassen each situate the processes of social production 
and replication within the city, and within this urban framing, Harvey and Sassen uncover the contribution of economics to inequality in socially produced spaces, and De Certeau considers how people respond to the naturalized hierarchy and hegemony of these every day spaces.

Harvey (2000) and De Certeau (1988), writing about the city, agree that its built form is the result of social process, and particularly one that is utopian and reliant on the stabilization and rationalization of those social practices. Assuming the social nature of built environments, both Harvey and De Certeau are concerned with the ways that cities maintain and reproduce the social processes which preceded them. The problem for Harvey is that he understands the city as the culmination of the developmental state and capital accumulation (2000, 173). Since, as Marx tells us, capital is never satisfied, when the city is centered on capital, the city will also be centered on the inequalities that capitalism necessitates. Though not steeped in the language of Marx, De Certeau is also concerned with the socioeconomic and political realities that produce the space of a city. Briefly, this happens through rational, administrative distributions of space that serve for the city to maintain itself against interior or exterior "pollution", which is often cast as the “other" $(1988,94)$.

De Certeau differentiates between "strategy" and "tactic" to draw out the ways that power and space interact, where the most basic difference is that "strategy" is the privilege of those in power to shape space, and 'tactic' is the tool of the other to use, manipulate, or divert spaces. De Certeau writes, "if in discourse the city serves as a totalizing and almost mythical landmark for socioeconomic and political strategies, urban life increasingly permits the re-emergence of the element that the urbanisitic project 
excluded" $(1988,95)$. So the built city is not only the product of our architectural imaginings, as Marx says, but it is also a spatial indicator which humans respond to in ways which correspond to their perceived inclusion to or exclusion from the built space. The collective practices give rise to the city as a disciplinary space $(1988,96)$ where those in power can manipulate the space to protect it from external competition (1988, 36). Those in power use strategy to maintain their power by reinforcing their own position, by recasting the "other" as objects to be observed, measured and controlled, and by enabling the production of knowledge where the powerful are able to create and maintain a space as their own, including through the use of military and science (1988, 36). When De Certeau writes that the city is an "urbanistic project", then, he refers to the privilege of the powerful, who have designed the city to maintain their status quo. "Urban life" refers to all that exists in a city, including those on the other end of the power structure, who challenge, and are challenged by the "urbanistic projects" which are designed, implicitly or explicitly, to keep the marginalized marginal.

According to De Certeau, the "other" challenges the urbanistic project through "tactic", the ability to appropriate space and recast the meaning of it. Tactic is defined both in terms of who completes the action (the "other") and in terms of the difference in how space is used by the other relative to how the space is intended to be used. Tactics are decentered, calculated actions that deal with the space and structures of the empowered "blow by blow". The other must act when opportunities present themselves, not when they want to act (37). Through the use of tactic, the other brings herself back into the urbanistic project, refusing to be totally marginalized.

What does tactic look like? Tactic can be as subtle as the way the other moves 
through urban space. De Certeau adapts the literary terminology of synecdoche to make this point. Synecdoche, in its spatial adaptation, is emphasizing a spatial element so as to give it representational power. For example, a photo of a bicycle in a shop window can be used to represent a street or a neighborhood (101). This concept is useful in considering access to transnational space because people who do not have access to transnational space via communications technologies will need powerful tools of representation to reach the transnational. Tactics that allow local actors to make punctuated, but loud messages, suggest a useful strategy in reaching transnational spaces.

De Certeau helps us to consider the kinds of relationships those who live in societies of unequal resource distribution may develop with places that act as network hubs. Othered people may make tactical use of the space around the place, to attract the attention of, inform, or otherwise engage with the networks in that place. They may engage differently with different networks, or try to reach them all at once. 


\section{References}

Castells, M. (2012). Networks of outrage and hope: social movements in the Internet age Cambridge, UK: Polity.

--------. (2009). Communication power. Oxford: Oxford University Press.

Harvey, D. (2000) Spaces of Hope. Berkeley: University Of California Press, 2000.

Keck, M. E. \& Sikkink, K. (1998). Activists beyond borders: advocacy networks in international politics. Ithaca, NY: Cornell University Press.

Sassen, S. (2007). "The global city: a new frontier." Talk delivered at Syracuse University School of Architecture. Accessed 12-15-13 https://www.youtube.com/watch?v=f0D6pDzRmsM.

--------. (2006). Territory, authority, rights: from medieval to global assemblages. Princeton, N.J.: Princeton University Press.

-------. (2001). The global city: New York, London, Tokyo, $2^{\text {nd }}$ edition. Princeton, NJ: Princeton University Press.

Tarrow, S. (2005). The new transnational activism. New York: Cambridge University Press. 


\section{CHAPTER III \\ TRANSNATIONAL PALESTINE}

Introduction

Extant literature on the Apartheid Wall privileges the Wall's function in border-making, while ignoring other discursive and spatial functions it fulfills. This chapter reaches beyond the binational and border-making framing of the Wall, resituating it instead as a node among transnational networks of activism and tourism. By analyzing interactions between these networks and the spaces that form around the wall, this chapter highlights their dynamic nature, demonstrating how they create access to transnational space for Palestinians. First, I situate the Israeli Apartheid wall as a spatial practice of occupation and construct a brief history of the occupation through the lens of Israeli spatial control of Palestine and Palestinians. By casting the Wall as a strategy of the occupation, this section identifies the various narratives of separation surrounding the Wall-Israeli Jewish from Palestinian, Palestinian from Palestinian, Palestinian from land, emphasizing what is at stake for actors on either side of the Wall. Then, I consider the occupation from a transnational lens, noting the limits of a binational framing. The transnational approach gestures toward the myriad transnational networks concerned with the practice of occupation in Palestine. In particular, I explore activist and tourist networks. Tracing their connections to the spatial practices of the occupation, and especially the 
consequences of the Wall, reveals the different flows between space and networks identified in chapter one, and anticipates the relationships graffiti develops with space and networks, which is the subject of the chapter three.

This chapter will also critically apply De Certeau's conceptual distinction between strategy and tactic to the case of occupation. The distinction between strategy and tactic works in an urban setting, but how does it play into a transnationalized occupation? De Certeau's strategy-or-tactic dyad limits the effects of an individual's response so that an individual can only reorganize spatial practice, but not change the strategies or structures of the power. In his writing on structural violence, Galtung would agree with De Certeau. Individuals cannot overcome structural violence, which needs structural solutions (Galtung 1969). By reading Galtung into De Certeau, it seems there is room for spatial interaction between strategy and tactic, where organized individuals structurally challenge the built and social structures which oppress them. If the Wall is a strategy of occupation, that is, a part of a built environment which controls spatial practice to maintain and reinforce power dynamics, then we can understand networks that work against the Wall as a mode of tactic. Networks are tactical in so far as they are the tool of the other, they are not spatially or institutionally localized, and they are determined by the absence of power (De Certeau 1984, xix, 38). A direct application of De Certeau's tactic would suggest that Palestinians are able to change the meaning of the wall and its spatial repercussions through engagement with networks. The effects of those networks, however, reach beyond spatial practice near the wall. Many of the networks are engaged in activities outside of Palestine, including networks that are focused on challenging the legality of the Wall and other structures of the occupation. By challenging not just the 
spatial practice, but also the structures and strategies of occupation, the work of networks at the Wall suggest a new mode of tactic that does more than promote Palestinian visibility.

\section{A Bi-national Wall?}

The Introduction presents Jung's analytical frames to identify and critique the dominant, state-centered perspectives in studies of Palestine and Israel. Reframing the occupation of Palestine in transnational language is necessary for several reasons. Most importantly, as the Introduction asserts, state-centered framing is limited to vertical, international approaches. Chapter two's discussion of the transnational highlighted the work of Fraser and Sassen to show that transnational connections are forged through horizontal linkages rather than vertical ones (Fraser 2008, Sassen 2006). Given the statelessness of Palestine, and further, the questionable legitimacy of its proto-state organizations including the PLO in the past, and the PA presently, state-centered frames are not able to adequately account for Palestinian agency in the dynamics of the occupation. Further, because there is not a state that acts on behalf of Palestinians, tracking Palestinian political activity and agency requires a bottom-up perspective.

Non-state frames allow us to ask how everyday Palestinians exist with and against the structures of occupation, and not simply what the occupation does to Palestinian life. Turning from the top-down frames Jung identifies, I propose a new system of frames which reveals the connections between everyday Palestinian life and the transnational. This chapter argues for a network/space frame to draw out the relationships Palestinians make with transnational actors in Palestine. In this frame, I argue that 
perspectives on the Israeli occupation become evident in thinking about the ways that actors - Palestinian, Israeli, and transnational -respond to and act against different components of the occupation. This new frame draws attention to the actions of networks in Palestine, and how those networks interact with the spatial controls of the occupation. Because the transnational takes place in network/space interactions, the kinds of spaces created by the occupation, and especially the Wall, must be identified first. Then, through highlighting the interactions of selected networks in those spaces, the transnational can be located in Palestine.

\section{Occupation as Spatial Practice}

A discussion of the Palestine-Israeli Apartheid wall should be set against the context of $20^{\text {th }}$ and $21^{\text {st }}$ century walls that have materialized in many different parts of the world. They include the Berlin wall, the US-Mexican wall, the India-Pakistan wall, the North-South Korean wall, the Morocco-Western Saharan wall, the walls around the bantustans of Apartheid South Africa, the Northern-Southern Cypriot wall, and the North-South Irish wall. More specifically, the Palestine-Israeli wall ought to be considered in the context of other post-colonial era walls, because, as Jassal and Ben-Ari show, the practices of colonization and occupation which led to the present occupation of Palestine have their roots in the very same colonial practices and failed attempts at decolonization that have gave rise to so many of the other walls listed above (2007).

When the Palestine-Israeli wall is thus contextualized, we work past the Zionist myth of particularity, which Israel uses to prioritize the "security apparatus" no matter the consequences. By calling into question the supporting details of the security argument, 
academics and journalists have opened up space to consider other functions of the wall. Former Israeli Prime Minister Ariel Sharon and current Prime Minister Benjamin Netanyahu have linked the building of the Wall to a measured decrease in Palestinian attacks against Israeli civilians, and have publicly asserted that the Wall is necessary for the survival of the Israeli state and its people. A 2006 Haaretz report casts doubt on the linkages Sharon and Netanyahu have indicated, citing official statements from Shin Bet, the Israeli central intelligence. The statements confirm the drop in Palestinian attacks, linking them instead to the 2005 Hamas ceasefire. Further, the Shin Bet argues that the Wall has not improved security measures on the Israeli side, citing attacks prior to the 2005 ceasefire which easily penetrated gaps or unfinished sections along the Wall (Haaretz 2006). Even from an architectural perspective, some have cast doubt on the defensive purpose of the Wall. Indeed, as one architect notes, walls of defense are built in straight lines, they do not slither as the Apartheid Wall does (Sorkin 2005, x). Whether the Wall has actually contributed to increased security for Israeli Jews or not, there seem to be other motives afoot in motivating its construction and path.

By decentering the claims of security, we can look with greater care to the other functions of the Wall, and particularly its control over Palestinian space and narratives of separation and dispossession. Discussions of the various colonial functions of the Wall will elucidate two important processes. First, it indicates the kinds of space created around the Wall, including the enveloped spaces which Palestinians must navigate in to live alongside the Wall. By understanding how the Wall forms some aspects of Palestinian spatial practice, such as separation of people from agricultural lands, and separation of major cities from each other, the Wall's role as a tool of occupation is 
evident. By looking at how Palestinians tactically respond to the elements of the Wall's occupational control, a second process is made visible. Mapping some of the interactions between the functions of the wall and spatial interaction in Palestine will identify which networks converge around the created space of the Wall, and how those networks and spaces interact.

In recent years, Israeli geographers and architects have critically assessed how Israeli spatial practice and built environments have contributed to the displacement of Palestinians. Sometimes historical, sometimes contemporary, these critiques provide new ways of understanding the Israeli occupation of Palestine and its effects on the Palestinian people. While the ongoing construction of the Apartheid Wall provides one of the most obvious and most politicized examples of Israeli control over Palestinian space, historical accounts from the British Mandate era and the earliest years of the Israeli state will place the Wall among a history of Israeli spatial control over Palestinian land, water, and airways. Articulating this historical continuity is significant because it contextualizes the case of Palestinian graffiti as an anti-occupation tactic, a case which will be addressed in chapter 3. Though the occupation of Palestine was born into a transnational context (regardless of an 1880-1890,1948, or 1967 start date to the occupation), the graffiti on the Apartheid wall provides a rare account of Palestinian tactic that attempts to reach out to transnational networks.

\section{What's in a Name?}

The Israeli government began construction on the Wall in 2002 as a response to the second Palestinian Intifada, arguing that it was necessary to protect against 
Palestinian attacks on civilians. The Israeli government, keen on maintaining its narrative of victimhood in a hostile region, sees the wall as necessary to its survival and thus call it a "security fence" or "security barrier" (Shlomo \& Fenster 2011, Jones 2009, Baskin 2002). This moniker reinforces the Israeli narrative by highlighting the supposed role it plays in the securitization and protection of Israelis, and also deemphasizes the devastating permanent impact it has on Palestinians.

Israeli politicians cling to the security argument despite numerous studies that reveal the dubious nature of claims that the wall does, in fact, produce security for Israeli Jews. Israelis and Israeli academics point to other spatial benefits of wall for Israeli Jews. The most racially driven "benefit" is Ehud Barak's argument for the need to keep Israel Jewish only, and extension of the ideals of labor Zionism, which is a socialist adaptation of Zionist ideology (Jones 2009, 18 and Baskin 2002, 7-8). Other economic arguments suggest that Israel, as the only developed economy of the Middle East, has much to lose by integrating with the Palestinian and other Arab economies, and as such, needs to completely close off its borders and economy. In this argument, the Wall is seen as a necessary tool to keep "illegal" Palestinian laborers from entering Israel to fill seasonal agricultural jobs $(2002,8)$. Finally, citing violence at checkpoints, there are some who suggest that peace will come from separation. This argument points to the tensions and violence that occurs at checkpoints, and it asserts that if the location of violence is omitted, the violence will end $(2002,9)$. That the racist overtones of these arguments dovetail so seamlessly with the racism of the occupation suggests that even despite the veneer of security, the Wall readily finds support.

Those concerned with the effects of the wall on the other side, by contrast, focus 
on the Wall's tragic impact on many aspects of Palestinian life, including separating Palestinians from their agricultural lands, from their families, and from their schools and work (Alatout 2009, Jones 2009, Hanauer 2011, Eidelmann 2011). The choice of many to refer to the Wall as the "separation barrier" draws attention to and privileges the many narratives of separation over the other functions of the Wall (Hanauer 2011, Eidelmann 2011, Pallister-Wilkins 2011, Khalidi 2005, Said 2003). Some want to highlight the racial overtones of the separation and refer to the Wall as a "segregation wall" (Isaac 2009a, 2009b). And still others, including this thesis, seek a name which captures the context of the Wall beyond its immediate effects, Apartheid Wall. The name "Apartheid Wall" still situates the Wall as a tool of spatial practice and concretized national binary, but it also begins to gesture toward the transnational linkages this chapter sets out.

The name "Apartheid Wall" is eschewed by some, who desire a more careful reading between Apartheid South Africa and the Israeli occupation of Palestine (Alatout 2009, Omer 2009). Omer argues the analogy needs to be nuanced so we do not fall into a "trap of over-likeness", where issues of boundaries, identities, and justice become conflated between Palestinians and black South Africans, but she also warns against letting the Israeli security narrative justify itself through "hyper difference" (2009). As I have argued, the Zionist myth of exceptionalism underpins the settler-colonialist mentality upon which Israel was built. By situating Israeli practices of occupation among other similar colonial practices, the defensive narratives of "hyper difference" are challenged. To avoid the conflation that Omer warns of, what follows next is a brief discussion of the institutional similarities between occupied Palestine and Apartheid South Africa, followed by a case of the Palestinian inexperience. Showing the details of 
the Palestinian experiences against the broader strokes of late twentieth century settler colonialism will illustrate, with sensitivity, the similarities and the importance of differences between the South African and Palestinian cases.

Those who refer to the Apartheid Wall as such, draw linkages not just between the Wall in Palestine-Israel and the walls surrounding bantustans in South Africa, but also to the historical contexts of both systems of rule, and to the effects of the rule on subjugated populations (Gould 2014, Higgins-Desbiolles 2011, Tawil-Souri 2011, Yiftachel 2010, Omer 2009). Apartheid South Africa and the state of Israel, both "colonial-settler state[s] predicated on ethnic, national, and religious separation" came to be in 1948, on the heels of global-scale decolonization movements elsewhere (Hasan 2008). Laws in South Africa were created to enforce racial segregation within a national boundary. First, laws focused on institutional inequalities that granted unequal access to social services, and then later extended to physical separation (Dugard and Reynolds 2013, 4). This can be equated with post-Oslo Palestine, where police force, military, and even the governing body (the Palestinian Authority) are subject to Israeli management. Palestinians cannot make economic, political, or other kinds of international agreements without Israeli approval. Both Israel and Apartheid South Africa have/had laws guaranteeing a majority of the land for settler-colonists, both require(d) subjugated populations to carry ID cards as a means of policing and restricting movement, and in both cases the subjugated populations are/were subject to extrajudicial arrests and killings (Dugard and Reynolds 2013, 5, 1819). Regardless of the language, the effect of these practices of occupation is that Palestine functions as a subsidiary of Israeli national institutions. Like the walls enclosing bantustans in South Africa, the Wall in Palestine is part of the extension of institutional 
inequality toward total physical separation.

Whatever the Wall is called, the significance of its impacts on Palestinian life and space cannot be overstated. The Wall creates different kinds of space for Palestinians and galvanizes different kinds of transnational attention and support for Palestinian self-rule. The following section expands on examples of the Wall's impact on Palestinians. This expansion serves to differentiate the Palestinian experience from the South African experience, but it will also highlight the limit of the binational and state-centered framing this chapter articulates. As long as the Wall is understood as a binational barrier of separation, Palestinians are cast as impotent against the Wall and its spatial imposition. As later sections of this chapter argue, once transnational elements are identified through the network/space frame, Palestinian agency against the Wall becomes more visible.

\section{Spaces of Separation}

When the emphasis of the Wall is on its function as a separation barrier, two distinct narratives of separation emerge. The first is Israeli Jewish separation from Palestinians, and the second is Palestinian separation from other Palestinians and land. Both types of separation involve complex and dynamic processes that result in the creation of different kinds of space on both sides of the Wall. In other words, though this section identifies two narratives of separation, the Wall does not create a Palestinian side

and an Israeli side. Rather, it casts spaces, sometimes overlapping, sometimes competing, on either side of the wall, and Palestinians and Israelis respond to varying spaces in various ways.

The political and social dynamics of the Israeli occupation have created a strong 
sense of other between Palestinians and Israeli Jews, and the presence of the Wall reifies this difference (Jassal and Ben-Ari 2007, 37). Both Brown and Alatout locate a paradox in national walls and the populations they seek to divide. While national walls create usand-them divisions that seek to separate populations from each other, they also create different kinds of exchange between the two populations.

Brown analyzes the resurgence of walls, once a medieval reinforcement, in the modern era (2011). For Brown, one of the great ironies of walls in the modern era is the fact that world is increasingly globalized and transnationalized, yet some states feel the need to reassert their boundaries through the construction of walls. Whereas the primary function of medieval walls was to provide physical security from dangerous outsiders, modern walls, Brown argues, are concerned with controlling flows of people symbolically.

Brown considers the San Jose section of the US-Mexico wall as one example of how modern walls function. In the city of San Jose, where the wall is subject to the most surveillance, it is also the most fortified, boasting three layers of wall $(2011,35: 00)$. Meanwhile, just a few miles out of town, the wall becomes a fence with holes, and likely, a crossing point for many undocumented workers. The implication is that the wall's claims of physical securitization are performative, and meanwhile, the wall serves as a continuous reminder to those living on the US side of the wall that there is a ubiquitous danger to contain on the other side of the wall.

The Wall in Palestine creates a similar symbolic effect between Palestinians and Israeli Jews and it may be particularly damaging in places such as Jerusalem, where Palestinians and Israeli Jews have lived in overlapping quarters for decades. As Israel 
began its work to recreate the built environment of Jerusalem, first through expelling Palestinians from neighborhoods and reconstructing those neighborhoods, then by building the Apartheid wall through remaining Arab neighborhoods, Israel has secured a built environment which enables the demonization of the other. Jerusalem's place as a mixed Palestinian/Israeli city has historically provided at least one space where Palestinians and Israeli Jews were forced to meet face to face as civilians, allowing for some level of humanization to occur (Yacoubai and Yiftachel 2005, 148). As Palestinians and Israeli Jews continue to lose opportunities and spaces of physical coexistence, the Wall becomes more than just an object of physical separation. It becomes a towering, daily reminder to both Palestinians and Israeli Jews of a dangerous, faceless other, who lives on the other side. And for Palestinians, the Wall continues in its role as a structure and occupational strategy that seeks to control Palestinian movement, especially with regards to accessing other Palestinians, and agricultural land.

Surveillance is one example of occupational strategy linked to the practice of separation. A defining feature of De Certeau's strategy is the mastery of place through sight, or the ability of those in power to transform the other into objects that are observed and controlled $(1988,36)$. Surveillance then, participates in the symbolic separation of Israeli Jews and Palestinians by reinforcing the power dynamics which distinguish "us" from "them", and, importantly, in the physical separation of Palestinians from Palestinians and land. Surveillance is enforced in many ways, including watch towers that dot the length of the Wall. At times weapons are visible, pointed at populated streets and walkways. Whether weapons are visible or not, soldiers are not, giving passersby the effect that they are always under surveillance. In this way, the Wall directly controls 
Palestinian movement, where they can and cannot travel, or even how they can travel, in cases where people, but not cars, can pass through certain sections of the Wall (Zureik 2007, 136).

Israeli control over Palestinian movement permeates all facets of Palestinian life, including visiting family, traveling to and from work, and even traditions such as wedding celebrations. Alatout provides cases of "porous sovereignty" in the Apartheid Wall in Palestine that resemble the inconsistencies Brown points to in the US-Mexico wall. One case involves a woman in Abu Dis, who lives across the road from her mother. The Wall was since built through that road, and rather than crossing the street this woman now has walk six kilometers down the length of the wall, where she illegally crosses it to visit her mother. Most days soldiers watch from a distance as the woman crosses, but occasionally they stop her and turn her back $(2009,963)$. In another case, the Wall threatened to cut off a Palestinian woman's route to work. When she appealed to the Israeli courts, they halted construction of the wall in her neighborhood and built a locked gate instead. This gate is not guarded by soldiers. Rather the Palestinian woman holds a key for it, unlocking and then locking it each day to go to work $(2009,964)$. Both of these examples suggest a Wall which is not functioning as a separation barrier in a literal sense. In both cases, the women are able to cross the Wall, one "legally" and the other "illegally". The woman with the key can choose to leave the gate open and allow others to cross, or she can choose to to lock other Palestinians out each day she leaves for work (Alatout 2009, 964). In the case of the woman who visits her mother, the Wall and its controls over Palestinian movement serve to criminalize Palestinian movement even within the green line (Ghanim 2007, 285-6). When the wall cuts through Palestinian 
communities and families, visiting family and other acts of "normality" become criminalized when Palestinians do not have a permit (Ghanim 2007, 291-2). And even when permits are available, the wall can complicate basic cultural practices such as marriage. Shlomo \& Fenster study the wall's impact on Palestinian communities in East Jerusalem, highlighting the effects of the wall on breaking up families, as well as complications in marriages between Jerusalem families and West Bank families. In the case of the weddings, it is very difficult for West Bank residents to get permission to enter Jerusalem, so, as Shlomo \& Fenster indicate, wedding traditions, where the bride and grooms families visit each other before the wedding, need to be altered $(2011,60)$. These examples illustrate what De Certeau meant when he said that mastery of sight was part of strategy. The Wall serves as a tool that Israel uses to create the illusions of separation, and it serves as a daily reminder to both Israeli Jews and Palestinians of the other. Additionally, for Palestinians, the Wall creates spaces that reinforce or challenge identity, legal status, and cultural practice. Significantly, Brown and Alatout do not understand the wall as a static object. The wall, its irregularities and inconsistencies are a necessary and relevant part of their story. In fact, it is the inconsistencies themselves, and the way that Palestinians and Israelis respond to them that make the stories Brown and Alatout are interested in. Rather than emphasizing how communities are reacting to or are affected by the wall, and constituting the Palestinians and Israelis as subjects in their stories, both Brown and Alatout constitute the wall as agent and look at how the wall changes the space in which Palestinians and Israelis act. Importantly, both also look past the function of the wall in nationalist narratives, where the wall is either a security device or a thing which separates Palestinians from land and people. Instead, Brown and Alatout 
look toward ways the wall, and Palestinian and Israeli interactions with it, have the potential to continuously and differently effect people's relationship to the space around the wall.

The bi-national contexts of the Wall are an important starting point in contextualizing how the Wall factors into the national perspectives of the two nations most directly impacted by the Wall. However, as this thesis argues, the Wall's impact reaches beyond Palestine and Israel. The spacial interactions Brown and Alatout point to are an important stepping stone for thinking past the nationalist narratives and the limited analyses produced by those narratives. When the Wall is understood as part of a built environment that produces many spatial relationships, rather than looking to the immediate effects or purposes of the Wall (securitization/separation), one can look to the spaces it creates to look to other processes the Wall participates in. The following section uncovers the dialogue with transnational networks some of the spaces are engaged in. Like the Israeli occupation of Palestine itself, the Wall is rooted in processes of transnationalization and globalization.

\section{A Wall that Connects}

Chapter two argued networks and space are dialogically related. Thus, on one hand, networks surrounding the Apartheid wall are shaped by the conditions of the local space which are created by the wall. On the other hand, they also shape the ways local space is created, charged, and consumed but the local actors. One of the many paradoxes of the wall is that even as it divides spaces, it also creates them. Not only does the Wall demarcate where one national space ends and another begins, it also connects 
Palestinians to a transnational community. This happens in part because of the ways the wall has attracted the attention of transnational actors, who respond to the wall in different ways, especially through tourism and activism. There is a dialectical effect here, where the wall creates a space around itself that attracts different people for different and overlapping reasons. One way this might be envisioned is thinking of a two-dimensional representation of the Wall with a Venn diagram encompassing the Wall. In a transnational framing, the shaded circles of the Venn diagram include the spaces of religious tourists, occupation tourists, and activists. The spaces around the Wall can refer to any combination of those three categories of actors. Within any of those spatial overlaps, one can look to how the Wall and the different networks organized in spaces around the Wall are in an ongoing process of influencing and being influenced by one another.

The transnational networks explored in this section are activists, religious tourists, and occupation tourists. The two networks of tourists are treated a collectivities, but activist networks, who tend to operate in an organizational capacity, are differentiated. By focusing on prominent activist networks, this section will provide examples of the dialectical process between networks and space chapter two identified.

Anarchists against the wall have a distaste for the wall's violation of armistice lines, etc. and protest against that. For ISM, the wall is just another outgrowth of the occupation. For Christian pilgrims, the wall is an inconvenient barrier, especially in Bethlehem. For occupation tourists, the wall and its effects are often the primary focus of the trip. Each of these different networks interact with the space of the wall in different ways. 
First, I consider how networks and groups are shaped by the wall. The Israeli control of Palestinian space through the practices of occupation has given rise to a number of anti-occupation networks and activist groups such as the International Solidarity Movement (ISM), Anarchists Against the Wall (AAW), and Boycott, Divestment Sanctions (BDS). Each of these networks have different relationships with the wall, and these relationships are based on the ways in which the organization situates itself against the wall. Though most of these networks predate the wall (AAW is a notable exception) and are organized against the broader practices of the occupation, the building of the wall impacted activist network mobilization, as well as which issues they mobilize around. For example, ISM has been active in trying to block Israeli demolitions of Palestinian homes and the Israeli burning of Palestinian olive orchards as well as to bring international attention and Israeli accountability to these actions. The case of the wall construction in the villages of Bil'in and Ni'lin provide one example of how the wall shapes activist networks. Both of these villages are peasant villages. Many of the inhabitants practice subsistence farming and rely on their olive orchards both for food and for the excess olive oil which they are able to barter with or sale. When the wall was built through both of these villages, it separated houses from olive orchards. The people of Bil'in and Ni'lin responded by protesting the wall and demanding access to their lands. The IDF often disrupted these protests by shooting tear gas into the crowds and arresting protestors. (The case of Bil'in was popularized by the 2011 documentary 5 Broken Cameras). ISM, which was previously interested in monitoring home and orchard demolitions, began attending these protests and raising awareness about the ways in which the wall functions in Palestinian space. The wall, as a new strategy of occupation, 
was added to the list of issues which ISM monitored and reported on.

These cases have illustrated how the wall shapes networks, but as I have indicated networks also influence local responses to the local space of the wall. In 5 Broken Cameras, one respondent discusses how the protests are different when there is an international presence. In a separate interview excerpt, one Israeli indicates changing rules of IDF conduct when Israeli and international actors are presents, versus when it is only Palestinian actors. For example, soldiers cannot open fire on the crowd when Israelis and international actors are present (Hatuka 2012, 354).

\section{Tourism Networks}

Chapter two discussed tourism interaction with local space. The case of tourism in Kathmandu demonstrated how Nepali business owners responded to and supplied the wants of international tourists, creating "authentic", psychedelic, or affordably posh versions of Kathmandu. This example suggests that in cases of tourism, locals are aware of and cater to the wants of tourists, and that tourists seek pieces or experiences of their imagined-localisms to take home with them. Like tourism in Nepal, tourism in Palestine is subject to a process of internationals seeking an imagined Palestine. Though the kinds of imagined Palestines tourist bring with them to Palestine vary and overlap, I suggest three broad typologies that create different kinds of space. In some cases, Christian pilgrims go to see the "holy land" (and are often dismayed at the unbiblical modernity which greets them), occupation tourists want to see oppression in action (and are shocked to see Palestinians enjoying coffee and fresh juice in cafes), and educational tourists go to "live" the occupation during their 6 week study abroad at Bir Zeit University. In each of 
these cases, viewing the wall is a part of visiting Palestine, whether intentional or incidental. My argument is that different kinds of networks create different kinds of space in which others act and in turn shape those networks. Chapter three will pick up on the ways in which graffiti responds to those processes, but first I want to establish the ways in which these three tourist networks respond to the occupation and the wall and how they create and are created by different kinds of space.

Christian pilgrimage to Palestine centers in Bethlehem and Jerusalem. Incidentally, these are two cities in which the occupation is particularly visible because of the ways in which the wall snakes through them. Christian tourists come seeking religious sites and religious souvenirs, both of which are readily available in Bethlehem and Jerusalem. Bethlehem is riddled by the wall in a way which necessitates long, windy paths along the wall to get from one destination to the next. This means for tourists coming to Bethlehem, they must see long swaths of the wall, whether or not they mean to. It is not surprising to note, then, that the wall in and around Bethlehem is one of the most heavily graffitied portions of the wall. Though pilgrims and Christian tourists come from diverse political perspectives and likely garner varying opinions about the nature of the Israeli occupation of Palestine, two perspectives are found among this group which are not going to be found in activist networks-- those without any political context for the occupation, and Christian Zionists. In addition to the a/political perspectives of these tourists, another barrier between them and Palestinians emerges in the way in which "holy land" tours operate. Since 1967, Israel has maintained a monopoly on so-called holy land tours. Since important Christian sites such as the Sea of Galilee, Nazareth, and the Jordan River all lie beyond the 1967 borders, Israel is able to enforce that monopoly 
by not allowing Palestinian tourist companies to operate outside of the West Bank's shrinking 1967 borders. Further, Israeli tour companies allow their tour groups 1 hour in Bethlehem, 45 minutes to see the Church of the Nativity, and 15 minutes to shop (Isaac 2009, 27). The implications of each of these barriers suggest that there is not a much of a shared space between this particular group of tourists and Palestinians. In other words, Palestinians must reach far to reach out to these kinds of tourists and create space for them. One way Palestinians have traditionally reached out to pilgrims is through the sale of religious souvenirs.

The economy of Bethlehem traditionally relied upon tourism. Before the wall, Bethlehem's hotels and streets bustled during Christian holidays and other peak tourist seasons. Bethlehem markets, and especially those surrounding the Church of the Nativity and the Milk Grotto, were full of Christian artifacts, especially those items carved out of locally sourced olive wood, which has symbolic value for many Christians. After the construction of the wall, tourism in Bethlehem suffered, and so did the markets which sold these goods.

Occupation tourists participate in and create very different kinds of space. As indicated above, they often come to Palestine to see the wall and its effects on Palestinian life. Palestinians do not need to do much to reach out to these tourists, they often come to reach out to Palestinians. Palestinians are able to arrange tours, which bring Israelis and international tourists into some of the most devastating places of the occupation (Chaitin 2011). These are tourists who are likely to go beyond Jerusalem and Bethlehem, to sites of home demolitions, orchard burnings, and the urban occupation of Hebron, where settlers have literally occupied a unit in an apartment building in the middle of the city, 
causing the building and its immediate surroundings to be patrolled by the IDF. There is the potential for a lot of overlap between this group and activist networks, but not all occupation tourists participate in direct action solidarity work so the distinction here is meaningful.

Closely related to the occupation tourists are what I call the education tourists. Education tourism is closely linked to the new study abroad, where students go on immersion trips, usually for a few weeks in the summer, and earn college credit. Bir Zeit University, near Ramallah, is the host of one of such program, and each summer dozens of cosmopolitans attend their Palestine and Arabic Studies (PAS) program. Though the Bir Zeit program has an upstanding reputation, and thus attracts students for that reason, based on anecdotal evidence, I suggest another motivator, which is the desire to "experience" the occupation. These students often go on tours that the occupation tourists attend, have a better chance of meeting local Palestinians and creating networks, and are likely going to be allies. Their time in Palestine is spent dodging checkpoints (and often being allowed to pass without incident by the IDF), hearing stories of occupation, and experiencing Palestinian culture. Palestinians have already worked to create this space for education tourists just by offering the PAS program. There do not appear to be any studies which suggest ways in which the wall has impacted the PAS program, but like the activist groups who added the wall to the places in which they monitor, so too did the PAS program add wall visits to the weekend excursions which it organized for its students. 


\section{Conclusion}

In this chapter, I argued that the wall is a strategy of Israeli spatial control over Palestinian space and Palestinian life, and less a barrier for the security of Israeli Jews. Though hegemonic narratives which point to the wall's role in severely disrupting Palestinians lives are correct, their emphasis on the victimization of Palestinians removes the agency in which Palestinians act and seek to create networks with those who visit Palestine and connect to Palestine. Through discussing the ways in which the occupation of Palestine is transnationalized, and how these different networks and their members interact with Palestinians and the wall, it is evident that Palestinians are aware of the kinds of political perspectives represented by their supporters. This will be significant as we move forward to analyzing the kinds of graffiti that appear on the wall, and the ways in which the tactic of graffiti not only challenges the spaces created by the wall, but also links Palestinian anti-occupation voices into other networks which converge at the wall, such as tourist and activist networks. 


\section{References}

Baskin, G. (2002). Walls and fences: Consequences for israel and palestine. PalestineIsrael Journal of Politics, Economics \& Culture, 9(3).

Brown, W. (2011). "Porous Sovereignty, Walled Democracy." Accessed via I tunes, 10$15-2013$.

Chaitin, J. (2011). 'Here's the separation wall': Political tourism in the holy land. Conflict Resolution Quarterly, 29(1), 39-63.

Certeau, M. de. (1988, c1984). The practice of everyday life. Berkeley: University of California Press.

Collins, J. (2011). Global Palestine. New York: Columbia University Press.

--------. (2007). Global palestine: A collision for our time. Critique: Critical Middle Eastern Studies, 16(1), 3-18.

Eidelman, R. (2011). The separation wall in palestine: Artists love to hate it. Thamyris/Intersecting: Place, Sex \& Race, 21(1), 95-114.

Ghanim, H. (2007). Living in the shadow of emergency in Palestine. In The partition motif in contemporary conflicts. Jassal, S. T., Ben-Ari, E. (Eds.) New Delhi: Sage Publications.

Hanauer, D. I. (2011). The discursive construction of the separation wall at abu dis: Graffiti as political discourse. Journal of Language \& Politics, 10(3), 301-321. Isaac, R. K. (2009). Alternative tourism: Can the segregation wall in bethlehem be a tourist attraction? Tourism \& Hospitality: Planning \& Development, 6(3), 247.

Harel, Amos. Haaretz http://www.haaretz.com/print-edition/news/shin-bet-palestiniantruce-main-cause-for-reduced-terror-1.61607

Hatuka, T. (2012). Civilian consciousness of the mutable nature of borders: The power of appearance along a fragmented border in Israel/Palestine. Political Geography, 31, 347-357.

Isaac, R. K., \& Hodge, D. (2011). An exploratory study: Justice tourism in controversial areas. the case of palestine. Tourism Planning \& Development, 8(1), 101.

Isaac, R. K. (2010). Alternative tourism: New forms of tourism in bethlehem for the palestinian tourism industry. Current Issues in Tourism, 13(1), 21.

(2010). Moving from pilgrimage to responsible tourism: The case of palestine. Current Issues in Tourism, 13(6), 579. 
Jassal, S. T., Ben-Ari, E. (Eds.) (2007). The partition motif in contemporary conflicts. New Delhi: Sage Publications.

Jones, C. (2009). The writing on the wall: Israel, the security barrier and the future of zionism. Mediterranean Politics, 14(1), 3-20.

Khalidi, R. (2005). From the editor. Journal of Palestine Studies, 35(5).

Mitchell, T., Prakash, G., \& Shohat, E. (2003). Palestine in a transnational context. Social Text, 21(2).

Omer, A. (2009). 'It's nothing personal': The globalisation of justice, the transferability of protest, and the case of the palestine solidarity movement. Studies in Ethnicity \& Nationalism, 9(3), 497-518.

Pallister-Wilkins, P. (2011). The separation wall: A symbol of power and a site of resistance? Wiley-Blackwell. doi:10.1111/j.1467-8330.2010.00859.x

Said, E. (2003). A road map to where? London Review of Books. 25 (12).

Shlomo, O., \& Fenster, T. (2011). In the shadow of the wall and separation: Everyday life in east jerusalem. Palestine-Israel Journal of Politics, Economics \& Culture, 17(1), 54-63.

Smith, C. D. (2010). Palestine and the Arab-Israeli conflict. Boston: Bedford/St. Martin's.

Sorkin, M. (Ed.) (2005). Against the wall: Israel's barrier to peace. New York: New Press.

Stamatopoulou-Robbins, S. (2008). The joys and dangers of solidarity in palestine. $C R$ : The New Centennial Review, 8(2), 111-160.

Urry, J. (2002). The tourist gaze. London: Sage Publications.

Yaeger, P. (Ed.) (1996). The geography of identity. Ann Arbor: University of Michigan Press.

Yiftachel, O. (2010). From sharon to sharon: Spatial planning and separation regime in Israel/Palestine. HAGAR: Studies in Culture, Polity \& Identities, 10(1), 71-103.

Yiftachel, O., Yacobi, H. (2005). Barriers, walls, and dialectics: the shaping of "creeping Apartheid" in Israel/Palestine. In Against the wall: Israel's barrier to peace. Sorkin, M. (Ed.) New York: New Press. 
Zureik, E. (2007). Constructing Palestine through surveillance practices. In The partition motif in contemporary conflicts. Jassal, S. T., Ben-Ari, E. (Eds.) New Delhi: Sage Publications. 


\section{CHAPTER IV \\ GRAFFITI AND THE APARTHEID WALL}

Introduction

The transnationalization of graffiti on the Apartheid wall might be less significant if it happened incidentally, but a close analysis of graffiti in Palestine suggests that Palestinians and transnational activists are targeting transnational spaces through graffiti on the wall, and indeed trying to engage the different networks that pass through the wall. A historical contrast of the use of graffiti during the first Palestinian Intifada (1986-1993) and the graffiti of the Apartheid wall contextualize the ways in which Palestinians use graffiti as a communicative tactic, and how language is manipulated based on its target audience.

Graffiti is used as a political tactic in many different circumstances. Studies on graffiti in different social and political contexts show that context matters in determining meanings of graffiti (Lombard 2013, Creasap 2012, Doering 2009), and more importantly, so does access to power (Waldner \& Dobratz 2013, Doering 2009). Graffiti is often performed by marginalized groups who feel they have no other political recourse (Lombard 2013, Farmer \& Milo 2012, Hanauer 2011, Tsilimpounidi \& Walsh 2010, Peteet 1996, Oliver \& Steinberg 1990). Reading graffiti is not just about political contexts, however. Meanings are derived from the medium, the context, intentions of the 
artist, and the intended audience. To illustrate the intersections of the different facets of graffiti reading, consider the following examples of political graffiti in Greece and Mexico.

In Greece, immigrant communities experienced increasing ghettoization as well as physical abuse from law enforcement. During the riots in Greece in 2008, in areas where there was a lot of overlap between immigrant and Greek populations, there was a surge in graffiti and street art painted by immigrants protesting police brutality and other abuses they suffered (Tsilimpounidi \& Walsh 2010, 112). Political graffiti also plays a role in Chiapas, Mexico, where indigenous communities suffer great human rights abuses at the hands of the Mexican government. Due to strict government censorship, members of the indigenous community are not able to publicly speak out without severe government retribution. Graffiti provides an anonymous forum through which the community evades government censorship and publicly announces the abuses they suffer (Farmer \& Milos 2012). Through the graffiti, students in Chiapas try to reach the attention of international human rights organizations (Farmer \& Milos 2012, 418).

The examples of graffiti in Greece and Mexico point to the interconnectedness of artists' intentions, audience, and political context. In both cases the political context is one of repression and human rights abuses. In Greece, intersecting political contexts, starting with maltreatment of immigrant and bleeding into the widespread riots of 2008 , provided a political climate that motivated graffiti artists and produced an audience they desired. Graffiti is a tactic, through which the weak can make their voices heard. Audiences, real or imagined, were also a significant part of the graffiti in both cases and the intention of the artists was to reach those audiences. In the Mexican example, we are 
told that messages are framed to try and reach an international audience, while in Greece, the artists' intentions were to mobilize a particular audience to their cause (Tsilimpounidi \& Walsh 2010).

There are many parallels between the examples just discussed, and the use of graffiti during the first Palestinian Intifada (1986-1993).The first Intifada, or uprising, occurred during a period of intense Israeli repression and censorship of Palestinians. During the time leading up to and during the Intifada, city-wide curfews were not uncommon, Palestinians were not allowed to have a printing press, and any expression of Palestinian national identity, such as a flag or the colors of the Palestinian flag, were banned. Disobedience was severely punished through jailing and torture (Peteet 1996). Like immigrants in Greece and indigenous in Chiapas, Palestinians turned to graffiti as a political outlet, but the graffiti was intended for self-consumption. Analyses of the graffiti of this time period show that the political messages of Intifada-era graffiti acted as a way to circumvent the brutal censorship that the Israeli government imposed on Palestinians until the post-Oslo era. Without access to a national media, political expressions, or other elements of self-determination, graffiti was a way for Palestinians to transgress the censors and to express political messages, sometimes encouraging the continuance of the Intifada and its tactics of civil disobedience, sometimes asserting Fatah or Hamas dominance in an area, and still other times expressing Palestinian national identity (Bishara 2010, Peteet 1996, Oliver \& Steinberg 1990). What is interesting about this graffiti is that is was nearly always in Palestinian Arabic, and the slogans were references to localized (sometimes neighborhood specific) events. Peteet references the occasional use of English in the graffiti, but states that it was to target an international delegation 
that Palestinian actors knew would be coming through the area $(1996,145)$. Palestinians were able to evade the censors not just in the national arena, but also transnationally, a full decade before the Apartheid wall was even built.

The history of graffiti in occupied Palestine anticipates the claims this thesis presents on the nature of contemporary graffiti on the Apartheid wall. In short, those claims are that local Palestinian and transnational graffiti artists use the wall as a "global canvas" (Gould 2014) to communicate experiences of occupation to transnational audiences. The audiences are targeted by issue framing, and the messages and images circulated in a transnational arena through a combination of electronic media, published volumes of wall graffiti, and personal/tourist sharing of experiences. This process creates space for Palestinians to circumvent the contemporary censorship of stunted economic development, and participate in transnational spaces.

\section{Issue Framing}

Keck and Sikkink argue that issue framing is one of the most important aspects of transnational activism. Understanding their approach is useful in identifying some processes which contribute to the development of transnational space around the Apartheid wall. By "packaging" their cause or messages in a particular way, activists are able to reach expanded audiences and elicit favorable responses from those audiences. One example they consider is rainforest deforestation. When framed as an environmental issue, transnational activists were unable to reach broad audience. Activists in the global North realized that they could link this kind of deforestation to loss of home and livelihood of the indigenous forest dwellers, and thus frame deforestation as a human 
rights issue. When they did this, they realized greater success in their efforts to curb rainforest deforestation in Brazil (1998).

The boomerang pattern is a related component of the grassroots transnational approach Keck and Sikkink develop. This model articulates the relationship between transnational actors, local actors, and governments in the midst of advocacy campaigns. When a state government, State A, for example, is not receptive to the demands of its constituents, those constituents seek other avenues of change which transgress state boundaries. In Keck and Sikkink's model, transnational and local actors create NGOs which do the important work of sharing information about a local issue with a transnational audience. Transnational actors attempt to pressure their own government, as well as intergovernmental organizations, to pressure State A to make changes $(1998,12-$ 13). The boomerang pattern identifies the interplay between local actors and transnational actors in transnational causes, and suggests the importance of the ability of local actors to frame their cause in a way which attracts international support (like the attempts of graffiti artists in Chiapas, Mexico), as well as for transnational actors to frame the cause in ways which will appeal to their own governments.

The case of Palestinian Apartheid Wall graffiti makes some departures from the model which Keck and Sikkink develop. Most obviously, it is not against their own state that Palestinians act, but an occupying power. In a way, this represents the most extreme kind of interference between local actors and State A. In the case of Israel and Palestinians, Israel is not accountable to the Palestinian people or the international community to represent or provide for Palestinian demands, yet it exercises great power over Palestinian ability to so for themselves. Though Palestinians have tried in a number 
of ways, most notably the first and second Intifadas, to challenge the power of the occupation, they have turned toward transnational networks to try to find external powers who will challenge the occupation.

Keck and Sikkink's model also stems from examples where transnational actors act on behalf of local actors. In other words, it prioritizes the agency of the transnational actor over the agency of the local actor. In the example of rainforest deforestation, we see how it was not the indigenous of the rainforest who mobilized to save their land, but rather transnational actors who employed the existence of the indigenous in the rainforest to frame, and garner more support for their environmentalist agenda. In the Palestinian case, there is a complicated interplay between Palestinians and transnational activists. While Palestinians are in control of the messages they paint, it is not always clear who paints which messages. Further, it is generally transnational activists who circulate the images. In this process, the activists exert agency in how images are framed in the circulation. Some of the issues that derive from these imbalances are explored in greater detail below.

How activists frame their cause has great impact on who will respond to it and how they will respond. For example, in the graffiti of the First Intifada, issues were often framed in a national context. National framing was evident in the use of PalestinianArabic as the language of expression, through the use of the colors of the Palestinian national flag, and through communications related to national political parties such as Fatah and the nascent Hamas. The national framing largely caught the attention of those invested in the national struggle-- it acted as an organizing tool and source of information for Palestinians, and it was read as a threat and act of insubordination by the Israeli 
Occupying Forces who tried to cover up the graffiti as quickly as it appeared (Peteet 1996). In analyzing the content of the graffiti on the Apartheid wall, we can indicate different ways Palestinians frame their appeals to an international and transnational community, including language coding and content and location analyses.

The substantial use of English as the language of expression is one of the most telling indicators that the intended audience of the graffiti is transnational. One study of graffiti on the wall near East Jerusalem reveals that $66.7 \%$ of the graffiti is in English. Hebrew, the second most common language, is used only $14.1 \%$ of the time (Hanauer 2011). The use of English, the language of both the cosmopolitan and one of Israel's greatest allies is tactical and symbolic. Recall from the discussion of De Certeau in Chapter 1 that tactics are calculated actions by the weak that deal with the space and structures of the powerful. By using English, Palestinian and transnational graffiti artists subvert the intended meanings of the space surrounding the wall and challenge the occupation in a targeted way. De Certeau argues that tactic is limited by its nature of being reactive to strategy, but when English language graffiti creates opportunities for the images and their messages to circulate transnationally, and to link up with transnational activist networks who can apply pressure on their own governments and the Israeli government from the outside, the act of writing graffiti in English suggests a new mode of tactic.

\section{Graffiti Locations}

The occupation of Palestine, and especially the wall, is framed by different actors in different ways. In chapter two, I discussed some of the ways that the wall is framed, 
sometimes as a security device, other times as a physical border markers, and still others as a separation device. As Keck and Sikkink's arguments on framing forecast, the different frames of the wall complement different political narratives in Palestine/Israel. For graffiti artists who wish to reach certain audiences, it is important that they choose frames which will have the biggest impact on the target audience. Likewise, transnational actors and governments frame the Israeli occupation of Palestine and the construction of the Apartheid wall in different ways and to different degrees of success in garnering support. Not only do graffiti artists use English language graffiti, but they also frame the wall in terms that will resonate with transnational actors. Further, when transnational actors try to elicit support from their co-nationals or appeal to their government, they may introduce their own frames that vary greatly from the frames of the original graffiti artists.

The location of the graffiti adds a final dimension to what I see as tactical, intentional attempts at transnationalizing the messages and images on the Apartheid wall. Location can be thought of in at least two contexts. The first, is the choice of the Apartheid wall, rather than other city walls or buildings, and the second is the choice of locations along the wall. The use of the wall as a canvas for transnational messages is important given that the wall has become synecdochal in many representations of the occupation. Street art and graffiti exist along other surfaces in Palestine, but it is the contrast in content that is revealing. Refugee camps are another place where there is a lot of graffiti and street art. The art and graffiti I observed in refugee camps between 2009 and 2011 had more in common with the graffiti Peteet observed in Intifada-era Palestine than the graffiti on the present Apartheid wall. Notably, Arabic was the dominant 
language of expression, and even images were imbued with such localized symbolism that Palestinians not from the camp had only vague understandings of them. The difference between location and content of graffiti suggests to me that the wall, given its ubiquitous representation of occupation and its function as a tourist destination, is purposefully selected as a place where outsiders will view, and potentially help disseminate, the messages and images found along the wall.

Relatedly, the locations targeted along the wall also suggest a tactical use of location. Of the few studies of graffiti on the Apartheid wall, the focus is on graffiti in either Bethlehem (Olberg 2011, Parry 2010, Rokem 2010) or Abu Dis, a neighborhood of Jerusalem (Hanauer 2011, 2004). These important destinations, whose stretches of wall host not only large quantities of graffiti, but also some of the most popularized images, are important because they are most likely to be viewed and photographed by tourists. In addition to Bethlehem and Jerusalem's places as popular tourist destinations in Palestine, the strategies of the wall construction and its impact on these two cities and their inhabitants become synecdochal of the devastation the wall as a whole brings upon Palestinian communities. The choice of Palestinian and other graffiti artists to highlight and amplify the representational quality of these sections of the wall seems indicative of the new mode of tactic I am suggesting.

\section{Graffiti Themes}

This section builds off of those connections showing how the graffiti's relationship to the transnational is created. The content, electronic circulation and national identities of the graffiti artists each contribute to ways that the graffiti itself 
becomes transnational. This section focuses on two distinct processes that the graffiti content participates in. The first is how the graffiti creates dialogue with non-activist tourists in Palestine and the second is the interplay between content and its electronic circulation. In his systematic study of graffiti on Abu Dis, Hanauer identifies several "categories" of graffiti content that create or respond to transnational contexts, including

statements of direct state support and appeals to human rights abuses, and I add themes of Western Christianity to that list. Different networks create different kinds of spaces around the wall. In the following analyses of images and image themes, I draw connections between the images and those networks, indicating relationships that may form in the dialogue between actors at the wall and the images and text on the wall.

\section{Christian Themes}

Chapter two highlighted possible relationships Christian tourists have with Palestine and the occupation. Though there is overlap between pilgrims and activists, Christian tourism also creates a group of tourists who either do not have a context for contemporary political realities, or, who may Christian Zionists and thus have a sympathetic view toward the strategies of Israeli occupation. Graffiti artists who want to reach out to these tourists would likely turn toward a common discourse, Christian theology and symbolism, to reach Christian religious tourists.

One prevalent image across the wall is that of a dove with an olive branch in its mouth, a reference to Abrahamic story of the flood, central to Christian, as well as Jewish and Islamic teachings. Further, the dove and the olive branch both carry strong representations of peace in Western Christian traditions. The dove and the olive branch 
are rarely depicted alone. Rather, they are often embedded in other images which either fuse religious and political messages. In the few images I have found where the dove appears alone, it is still embellished with political and religious symbolism. One case is the silhouette of a dove, shaded in with a Palestinian flag which fades into an Israeli flag. This image, from Abu Dis/Jerusalem, presents an evocative statement of peaceful Palestinian-Israeli unity and co-existence (Image from Shalem and Wolf 2011, 79). Another case, also near Jerusalem, depicts a dove, with its wings outstretched and nailed to the wall (Parry 2011, 160-1). This image at once suggests the wall as the death of peace in Palestine, and likens that process to the crucifixion of Jesus. Throughout Bethlehem, a dove and olive branch appear, where the dove wears a khaki combat vest and crosshairs are painted over its heart (Parry 2011, 16-17).

More frequently, the dove and olive branch appear as one part of a bigger picture, sometimes integrated as a part of an explicit commentary on religion, and other times as an omen of peace. One Jerusalem example places the dove and olive branch among references to the Ten Commandments and Moses and the burning bush (Shalem and Wolf 2011, 67). By playing on themes shared between Jewish and Christian theology, artists are able to simultaneously respond to both Christian tourists and to Jews, inside and outside of Israel. In another mural near Bethlehem, a picture of the old city of Jerusalem prominently features the holy sites of Judaism, Christianity, and Islam. From the center of the Church of the Holy Sepulcher, which is to the far right of the picture, a ladder extends beyond the clouds, where a pair of hands reaches from the heavens to hold the ladder. A dove bearing an olive branch enters from the extreme left of the mural, signaling peace and an end to a Deluge-like catastrophe. The Dome of the Rock and the 
Wailing Wall are sandwiched between these expressions of Christian peace. Though one cannot miss the Evangelical framing of this co-existent peace, the mural also features the likeness of the Apartheid wall in the foreground, with the meters high planks knocked to the ground and many of them cracked and shattered (Image in Shalem and Wolf 2011, 160-1). The juxtaposition of stark, Christian imagery against the felled wall, the depiction of Christianity "saving" Jews and Muslims from themselves and each other, creates an explicit and motivating directive on how Christians ought to respond to the wall.

While the dove and olive branch appear to be the most recurrent Christian symbol in the graffiti surround Bethlehem and Jerusalem, crosses (Parry 2011 26-7; Shalem and Wolf 2011, 130, Jeffrey, n.d.), Bible verses (Parry 2011, 35 Shalem and Wolf 2011, 134), and Christmas trees (Shalem and Wolf 2011, 24, 144) also appear, either on their own, or, like the dove and olive branch, in embedded contexts. For example, a painting of a Christmas tree near Bethlehem is shown completely encircled by the wall (Shalem and Wolf, 144). The presence of this category of images in and around the Christian holy sites, and the relative lack of Christian themed graffiti elsewhere on the wall, indicates ways that graffiti explicitly targets a genre of references likely to be familiar to those who pass through particular places in Palestine. I conclude this section by way of describing one more stretch of the wall in Bethlehem, near Rachel's Tomb, an important site for each of the three largest Abrahamic faiths.

Rachel's Tomb fell under the jurisdiction of the Palestinian Authority in the Oslo negotiations during the $1990 \mathrm{~s}$, but as routes for the wall were announced, it was evident that Israel intended to illegally annex Rachel's Tomb with the wall. Before the site was completely annexed, and tourists still accessed Rachel's Tomb from the Bethlehem side 
of the wall, Bethlehem residents and others went to the wall with messages for the tourists. Just outside of a souvenir shop, a section of the wall contains layers of colorful messages. Whereas the Christian-themed graffiti discussed above is dispersed along the wall, the section in discussion contains several messages for a Christian audience. As tourists walk along the road to Rachel's Tomb and the souvenir shop, they see a large heart with a cross and "Issa" (Arabic for "Jesus) written inside of the heart, "God is great" written inside of another heart, a large cross alongside the text "Jesus died", another heart alongside "Jesus", and, amidst a number of drawings that appear to be children playing, the text, "May I HAVE peace PLEASE" (Parry 2011 26-7). It is as though the ones who painted this section of the wall wanted the wall to be part of the pilgrimage. As the Christian tourists prepared themselves for their spiritual journey, the wall beseeched them to think of Jesus' love, but not without considering it alongside the realities of the wall.

\section{Transnational Politics}

Many activists come to Palestine to witness the occupation and to show their solidarity with Palestinians. As chapter 2 indicated, solidarity is expressed in many ways. One important function that transnational activists fulfill is circulating the images from the wall. In order to mobilize against the occupation of Palestine in their home countries, transnational activists frame the occupation in terms of its human rights abuses, and show how the occupation has a direct impact in the home country, particularly with regards to tax dollars. The growing popularity of BDS campaigns are a great example of this process. Though EU countries are sometimes implicated in this, the majority of internet 
and BDS campaigns target the role of the US in providing financial support to Israel. Given Israel's consistent place as the top recipient of US foreign aid, this approach should not be surprising. A Haaretz report from 2013 indicated that since 1948, the US has provided Israel with approximately 233.7 billion dollars, adjusted for inflation (Coren and Feldman 2013). Other reports indicate the US gives upwards of 3 billion dollars annually for economic and military aid (Sharp 2013). Relatedly, much of the graffiti on the wall targets this relationship between US aid and the Israeli occupation, and for transnational activists who want to mobilize support in their home countries. Highlighting these images is one way in which they may draw attention to the nature of economic ties between the US and Israel.

Hanauer categorizes the graffiti that responds to the relationship between the US and Israel, as "the Americanization of the Wall" (2011, 311-12). Though I disagree that the presence of this graffiti makes the wall "American" in the way that Hanauer's label suggests, his finding that over $25 \%$ of the graffiti in Abu Dis that makes a transnational reference refers to US involvement $(2011,309)$ is significant, and suggests an important sub-genre of graffiti to consider in this analysis.

Sometime in 2010, a large mural critical of USAID appeared on the wall in Bethlehem. USAID (US Agency for International Development) has been the subject of Palestinian critique since it began doing work in the West Bank and Gaza Strip in 1994 (see Jad 2009 and Roy 1999 for discussions on this). USAID is a source of confusion and contradiction for some Palestinians, who watch as the US at once funds the Israeli occupation and is complicit with Israeli actions in the West Bank and Gaza Strip, while also funding development projects in Palestine which are often focused on alleviating 
problems caused by the occupation. As Roy indicates, development money spent on Palestinian development is not trusted because it comes from the same hand that funds Israeli arms acquisitions $(1999,78-9)$ and it now funds and provides logistical support for the construction of the wall. In 2010, a large mural was painted on the wall in Bethlehem, featuring the USAID logo and the text "Brought to you by USAID". In less-developed, but no less direct graffito, an all-caps "MADE IN USA" stamp is found throughout the wall in Bethlehem, and is typically placed beneath another image or text (Parry 2011, 18, 20, 42; Shalem and Wolf 2011, 144, 152). Another image in Bethlehem, featuring an American flag says, “AMERICA I WANT MY \$ BACK” (see image in Appendix). This image appears against other images on the wall of US flags with stars of David or dollar signs in place of the fifty-stars as well frequent use of text such as "Paid for by US taxes" (see appendix in Hanauer 2011 for these images). or a weeping statue of liberty.

In another image (see Appendix), two sentences are written next to each other, one in English, the other, Arabic. The English reads "US Stop supporting Apartheid" and the Arabic, "One day we will become what we want", a line from the beloved Palestinian poet Mahmoud Darwish. The text appears to have been written at the same time, and bears one signature, MK. This image represents a strong case of the code switching argument I have presented throughout this essay. It suggests the tactical use of English to target its audience, while tactically using Arabic to show solidarity and hope.

There are many ways Palestinians could frame their resistance to the wall, so the choice to name and shame US complicity in the wall and Israeli occupation is significant. One of the most striking things about this choice is the fact that it calls to question US actions rather than Israeli actions, and it is in this difference that we can observe tactical 
framing and the creation of transnational space. Rather than focusing on their own victimization from the occupation, or making appeals to their occupiers, Palestinians and transnational activists direct their graffiti toward a powerful country whose involvement and complicity in the occupation is evident from $\mathrm{UN}$ voting records to documentation of US foreign aid to Israel to the tear gas canisters Israeli soldiers use as live ammunition bearing "Made in USA" logos. Palestinian graffiti is not only connecting the ways in which the Israeli occupation is transnationalized, but by connecting it to US tax dollars, the graffiti also seems to be targeting the American people in an attempt to garner their support and action for the Palestinian cause.

\section{Whose Transnational Wall?}

The fact that the Bethlehem and Abu Dis/Jerusalem stretches of the wall are among the most visible to transnational actors are the same reasons which make those stretches the most likely to be graffitied by transnational activists. For this reason, it is simply impossible to know what is painted by local Palestinians, and what is painted by transnational activists. The obvious exception to this is the work of well-known international artists such as Ron English or Bansky, whose work has been identified and catalogued by Western audiences. The process of focusing on Western artists' art on the Apartheid wall bares the painful familiarity of Orientalism, where the constructed realities of the wall and its impact on Palestinian lives become not the focus, but the objectified backgrounds in the stories of named and important Western actors. In a project which emphasizes the importance of producing and circulating graffiti on the Apartheid wall, it is necessary to take pause and understand the power structures that are 
replicated in the act of graffiting the wall.

The case of internationally recognized artists represents a somewhat obvious example of power imbalance, especially since their work is identifiable to the trained eye and their celebrity is part of what draws people to their work on the Apartheid wall. But what about graffiti produced by activists without street credentials like Banksy? There is much less knowledge about who produces the myriad slogans, stencil art, and statements of support that cover that wall, leading us to a delicate terrain of imperialism through expressions of solidarity. We have already seen this dynamic in the example of transnational activists and the rainforest that Keck and Sikkink uncritically discussed. Their example provides evidence of how easy it is for transnational activists to assert their cause at the expense of local actors who bear the brunt of the outcomes. Gould raises a similar line of critique with regards to the production of graffiti on the wall.

Gould's approach questions the nameless, transnational activists who graffiti the wall in solidarity with Palestinians. Whereas the wall is a lived experience for Palestinians, for activists, it can never be more than a political symbol. And since activists can never understand or represent the realities of the wall denying Palestinians access to hospitals or their orchards, the motives of the graffiti artists should be questioned. Finally, since Palestinians are the ones who must live with the images, on the wall, they ought to have more input over what those images are $(2014,14)$. Gould's concerns about the long term effects of international activists use of the wall as a "global canvas" are rooted in a problem of representation $(2014,6)$. Since it is Palestinians, and not the transnational activists, who live with the wall and its spatial consequences, Gould suggests it is insensitive for outsiders to try to "represent" the occupation in graffitied 
snippets along the wall. Further, citing an anecdote from Banksy, where a Palestinian man chided the artist for trying to beautify the wall, Gould raises concerns about Palestinian agency in creating graffiti on the wall (Gould 2014, 7). Gould contrasts the graffiti of Bethlehem with the graffiti of Belfast, concluding that while the murals of Belfast, created by locals, are a form of political power, "Bethlehem's canvas has been superimposed against the will of local inhabitants" (Gould 2014, 7). Gould bases this conclusion on the anecdote from Bansky, as well as in the globalized themes found in the graffiti content. For example, Gould problematizes the use of WWII and Cold War Germany references, suggesting that the parallels weaken the language of resistance once found in Palestinian graffiti (Gould 2014, 7). In other words, Gould wants to maintain the particularity of the Palestinian case, and the Palestinian language of resistance.

Gould is right to be concerned about the effects of international presence in Palestine. Palestinian academics are increasingly critical of the role of the international community in Palestine since the post-Oslo race to peace development. Jad has termed this process the "NGOization" of Palestine, referring to the flood of international nonprofit organizations trying to do peace work there. Jad argues that the effect of these organizations has been a total co-optation of Palestinian civil society, and the Palestinian women's movement in particular, which is now dictated by donor agendas abroad, rather than based on the wants and needs of the Palestinians the organizations purport to represent (Jad 2009). Though Gould does not discuss Jad's piece or this related field of literature, her concerns of international activists co-opting the Palestinian liberation should be read alongside the concerns Jad raises about peace development, and both of these critiques become even more significant against the imperialist and Orientalist 
histories of Westerners in the Middle East.

Though Gould has identified one important perspective on the graffiti of transnational activists, by understanding how activists and networks interact with the wall and spaces of graffiti, and how Palestinians interact and are in dialogue with those spaces and networks, I think Gould's analysis looks past some of the important dynamics at play on and around the wall. For example, while Gould is right to address graffiti that draws parallels between Nazi and Cold War Germanies, the fact that the wall harkens to painful historical pasts which are not Palestinian, does not preclude that Palestinians are not part of this conceptualization process. What if this is the language of resistance Palestinians choose? More generally, Gould's implication that the globalization of the graffiti content is dismissive of Palestinian wants or needs suggests that there is not space for Palestinians to have globalized thoughts and ideas. Finally, as chapter two discussed, particularizing the struggles of Palestine/Israel is part of the Zionist myth to justify settler colonialism. Thus, Gould's critique that the language of Palestinian resistance must remain particular to Palestine needs to be carefully examined.

Part of Gould's miscalculation stems from her comparative analysis of English language versus Arabic language graffiti on the wall. Early in her essay, Gould dismisses Arabic graffiti as merely decorative $(2014,3)$. Later, she addresses the imbalance in international attention to Arabic language and English language graffiti. The Arabic language graffiti is much less inventoried than of the work of international artists, and, whereas the graffiti of transnational graffiti artists tends to be explicitly political, the Arabic graffiti is "allegorical and opaque", and thus, less attractive to foreign media (2014, 14). Conceptually, Gould raises some important issues that complement the 
imbalances I indicate at the beginning of this section, but Gould's argument rests on a linguistic binary where English language graffiti is conflated with international artistry and Arabic language graffiti is equated with Palestinian artistry. Significantly, though she cites Peteet's discussion of code switching during Intifada graffiti, Gould does not consider this possibility in contemporary Palestinian graffiti.

The central theme of this thesis is to point to the possibilities that are created by and for Palestinians through transnational networks which intersect at the Apartheid wall. As the historical accounts of chapter 2 indicate, Palestine and Palestinian liberation movements underwent a process of transnationalizing, especially at the grassroots political level. It is not surprising, then, to see the graffiti link up with transnational and solidarity issues around the globe, and throughout history. The fact that the wall bears messages from international artists directed toward a global audience does not mean that Palestinians are not part of this process. When we consider the historical contrasts and read the content of the first Intifada graffiti against the heavy censorship and curfews that existed then, and the lack of communications technologies to keep Palestinians connected, the overtly political and localized nature of the graffiti is logical. Since the construction of the wall in 2002, and the graffiti that soon followed, Palestinians have not experienced the kind of mass curfews and police state that existed during the first Intifada. In other words, the communicative and informative functions of the graffiti of the first Intifada, as defined by Peteet, were met through other means in post-Oslo Palestine. A new communicative need, staying connected with the transnational political developments in a globalizing era, emerged at this time. The Palestinian effort to reach this audience, and that audience's participation in dialogue through the networks and 
graffiti I have indicated, should be recognized.

In the narrow space I have indicated between Gould's concerns of the "global canvas" of the Apartheid wall being appropriated by transnational activists, and the Palestinian agency in creating linkages through the Apartheid wall and its graffiti, I suggest a final mode of Palestinian tactic in Palestinian graffiti on the wall, a palimpsestic use of the surface. Above, I argued that there are power structures in place which lead to the reproduction and distribution of Western produced images on the wall. Palestinians, who see tourists pass by the wall and photograph the same images time and time again, or who hear tourists ask where they can find certain images on the wall, are likely to have a sense of which images are more popular than others. The wall, with hundreds of kilometers in surface area on the Palestinian side, boasts no shortage of surface for someone to paint on the wall. If someone wanted to graffiti the wall, it seems odd that they would paint over another's image (intentions of erasure notwithstanding), unless there is an intended purpose.

President Kennedy's famous statement, "Ich bin ein Berliner” was graffitied on the wall by Joy van Erven, a famous Dutch artist. This is among the popular images from the wall that circulate in the West. A photo of this graffiti from 2011 provides just one example of the wall as palimpsest (Shalem and Wolf 2011, 150-1). Looking at this image, it is difficult to discern what van Ervan painted over, and what was painted over van Ervan's text. However, perfectly centered below van Ervan's all-caps, black text, and just below eye level, where, for this this of the wall there is no other graffiti, one graffiti artist wrote, "we want peace no occupation [sic]" (Shalem and Wolf 2011, 150-1). A recent Google search revealed that this section of the wall has since received several new 
layers of graffiti, including text which covers Kennedy's line, but for a period of time, anyone who saw or photographed this destination graffiti, also took along with them a peaceful message, most likely from a Palestinian. 


\section{References}

Coren, O. and Feldman, N. (2013). http://www.haaretz.com/business/u-s-aid-to-israeltotals-233-7b- over-six-decades.premium-1.510592

Farmer, L., \& Milos, R. (2012). Graffiti: Giving voice to the indigenous. DePaul Journal for Social Justice, 5(2), 409-419.

Jeffrey, P. No date. Untitled image. http://kairosphotos.photoshelter.com/image/I0000_yAFVOM0cYY

Kalerante, E., \& Mormori, P. (2005). Graffiti as a form of social and cultural conflict. International Journal of the Humanities, 3(4), 129-132.

Sharp, J. M. (2013). The Congressional Research Service's report "U.S. Foreign Aid to Israel," Specialist in Middle Eastern Affairs.

Tsilimpounidi, M. \& Aylwyn Walsh. (2011). Painting human rights: Mapping street art in athens. Journal of Arts and Communities, Special Amnesty International Issue on Human Rights, 2(2), 111-122.

West, C. (2010). Dr. Cornell west speaks about art and culture in a social movement doi:http://www.youtube.com/watch?v=783fMZeG8Ac 


\section{CHAPTER V}

\section{CONCLUSION}

Palestinian and other graffiti artists in Palestine choose many different themes to portray in their art on the Apartheid Wall in Palestine. The previous chapter focused on Christian and transnational political themes to argue that Palestinian and other graffiti artists tactically select their themes to engage the networks that converge in the spaces around the Apartheid Wall. Chapter three discussed how the Wall functions not only as a tool of occupation, but also as a piece of a built environment which creates spaces that people to respond to. Palestinian and Israeli national narratives have focused on the spaces of separation and securitization, and chapter three expanded on those narratives, arguing that decades old transnational networks in Palestine interact with the Wall, creating transnational space and the need for transnational narratives. The dialectical relationships between networks, space, and built environments were explored in chapter two.

Revealing the connections between these three concepts, and providing a historical context for the occupation and separation of Palestinians and Israelis created the foundations through which the relationship between transnational networks and graffiti in Palestine could be explored. In short, when Palestinians and others write graffiti on the Apartheid Wall, they are writing into transnational spaces.

Chapter four discussed the Wall as synecdochal of the occupation. Images of the 
Wall, with or without graffiti, continue to appear in visual representations of Palestine and the occupation. A flyer for a university class on visual culture in Palestine/Israel uses the Wall with graffiti by Palestinian artist, Sleiman Mansour, as its background. The iconic orange "Visit Palestine" poster, designed by Frank Kraus in the 1930s, is now reproduced with the concrete Wall covering the observer's view of the Jerusalem cityscape that was the focal point of the original poster. A popular Christmas image of Joseph leading a pregnant Mary across the desert to Bethlehem (an Orientalist misrepresentation of the landscape) now circulates with the Wall blocking Mary and Joseph's path. Secular versions have also appeared with Santa blocked by the Wall. These images and the Visit Palestine poster can be easily found in an internet image search.

These images are suggestive of many of the processes and connections this thesis uncovered. Each of the examples present an implied circulation of images of the Wall, they show an attempt to link the Wall to intellectual and religious pursuits and thus tap in to those transnational networks. Kraus, the designer of the "Visit Palestine" poster, was a Zionist and supported of the founding of a Jewish state in Palestine at the time he designed this poster. Superimposing the Wall on Kraus' poster, which notably refers to the land as Palestine, is suggestive of the ironies of what the Israeli state has become. The tactical use of the Wall in these images suggests another strain of analysis that one might look for, in finding the Wall's place in space-making in transnational networks.

By way of conclusion, I want to return to the physical Wall, toward a more recent campaign Palestinian activists started in 2013. Activists have found another way to reach out to transnational networks and raise awareness of the Wall and the occupation by tactically using the physical limits of place that the Wall imposes. The campaign is called 
the Right to Movement, and it is an international marathon that takes place in Bethlehem annually. The idea for the marathon came up when a Palestinian mused that because of the Wall's path, there is not even a 42 kilometer stretch of land on which to host marathon. As such, the course for the marathon includes looping through the city of Bethlehem until the distance of 42 kilometers is reached (Palestinemarathon.com).

There are many parallels between this event and the use of graffiti on the Apartheid Wall. The Right to Movement, rooted in place, tactically uses the Wall to connect to transnational networks. It creates transnational space around the Wall by inviting international actors to witness the Wall and by extension, life under occupation. The use of a marathon to attract internationals is a tactical way of connecting to transnational networks. This new kind of tourism creates a market for athletes in a sport that is popular in the West, and one that does not appear to be deeply rooted in Palestinian culture, though the repeated success of this event may be changing that. The marathon's course starts and ends at the Church of the Nativity, and the duration of the course follows the path of the Wall. Starting and stopping at the Christian site highlights the place of Christianity in Palestinian culture and creates a context for different networks, in this case athletic tourists and religious tourists, to overlap. That the path of the race follows the Wall, by some combination of necessity and tactical planning, I surmise, ensures that all of the runners will be at least passively aware of the some of the functions of the Wall.

In addition to the connections to networks, the Right to Movement creates an opportunity for many who might not otherwise travel to Palestine, to see the occupation. As the discussion of Kathmandu in chapter two outlined, the experiences of tourist 
activities are often shared in the form of stories and images when tourists return home. It appears that the planners of the Right to Movement are aware of the powers of tourism, as they state in their event description that one of the purposes of the event is to bring people and runners to see Palestine and Palestinians (Palestinemarathon.com). As chapters two and four indicated, souvenirs are also an important element of tourist networks. Marathon participants receive a certificate of participation, as well as a medal made from locally sourced olive tree wood (Palestinemarathon.com). The significance of olive wood both in Palestinian culture and in Western Christianity imbues this medal with the same kind of overlapping contexts that the race organizers appear to appeal to by beginning and ending the race at the Church of the Nativity.

No matter how we read the marathon's connections to transnational space and networks, the marathon draws out an argument that lies dormant in the preceding pages. Palestinians will continue to engage the world community in the Palestinian struggle for sovereignty in whatever creative, non-violent, and tactical ways they can imagine, until one day, they become what they want to be. 


\section{APPENDIX A}

\section{MAPS}

Figure 1: Map of Wall against 1967 armistice line

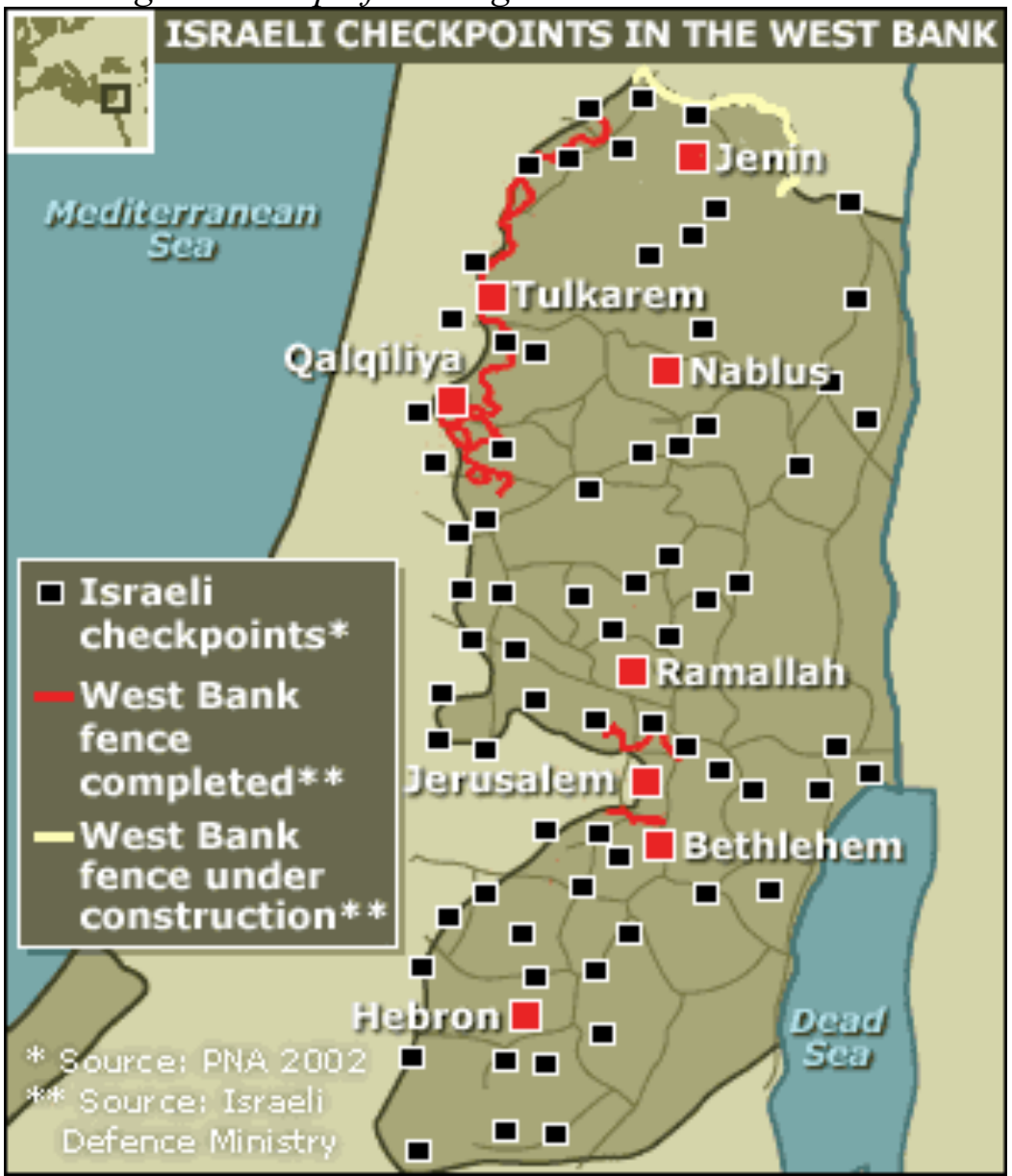

Source: BBC News

http://news.bbc.co.uk/2/shared/spl/hi/middle_east/03/v3_is rael_palestinians $/ \mathrm{maps} / \mathrm{html} / \mathrm{settlements \_ checkpoints.stm}$ 
Figure 2: Map of discontiguous West Bank

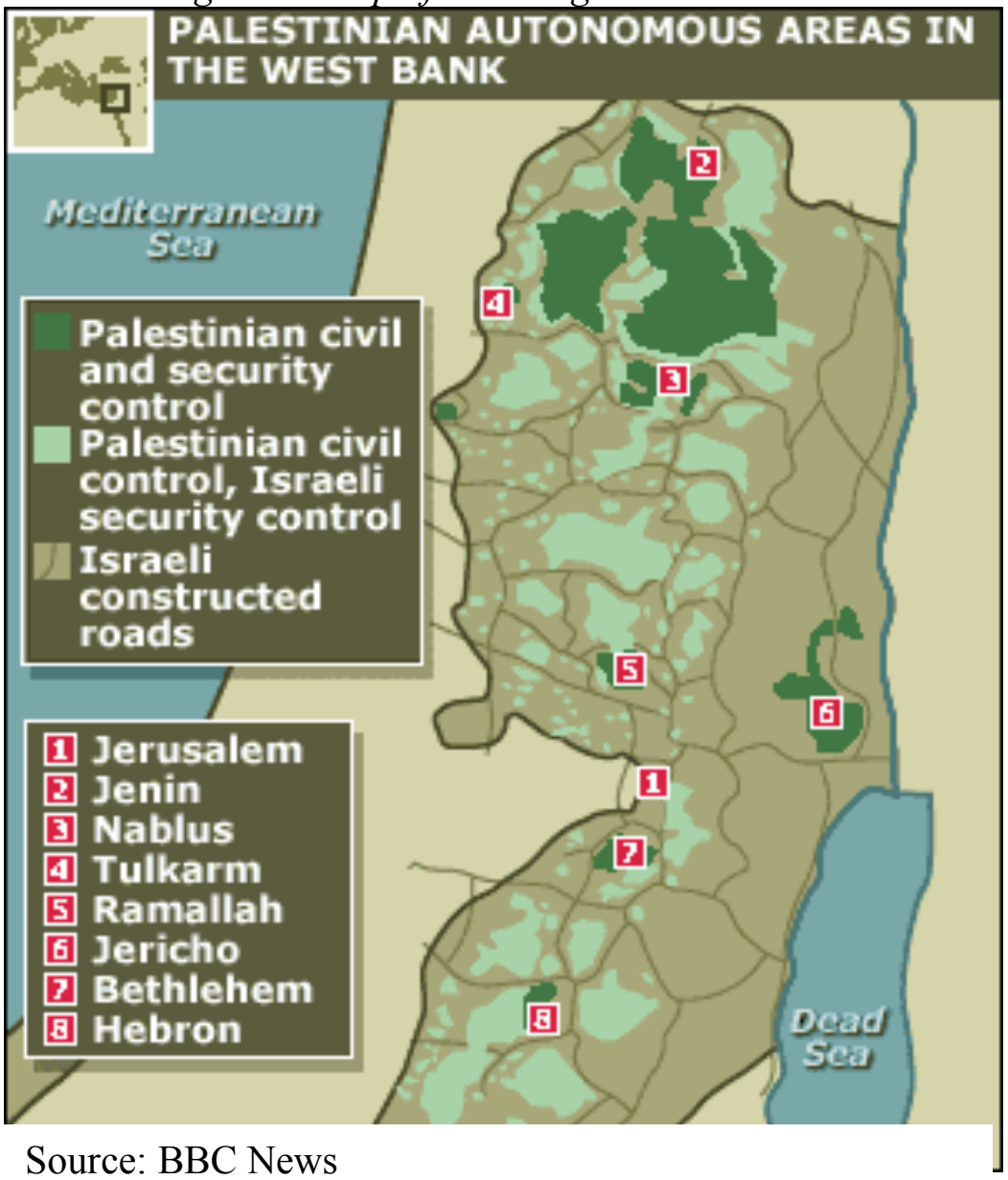

http://news.bbc.co.uk/2/shared/spl/hi/middle_east/03/v3_is rael_palestinians/maps/html/autonomy_population.stm 


\section{APPENDIX B}

HISTORICAL IMAGES OF GRAFFITI IN PALESTINE

Figure 3: The intifada continues...Hamas

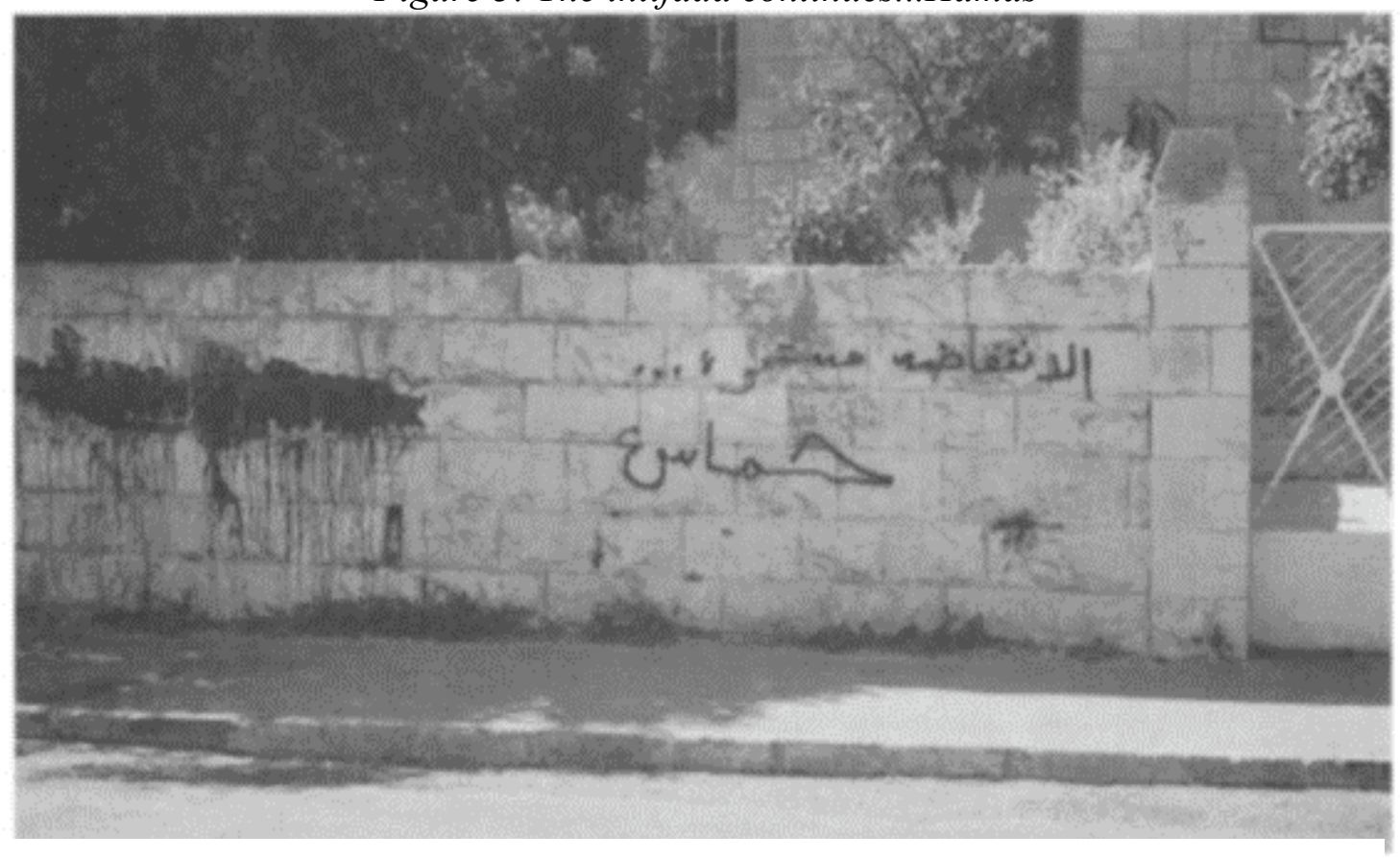

Source: Image and caption source: Peteet, J. (1996) The writing on the walls: the graffiti of the intifada. Cultural Anthropology, (2), 139. 
Figure 4: Fatah graffiti in Palestinian flag theme

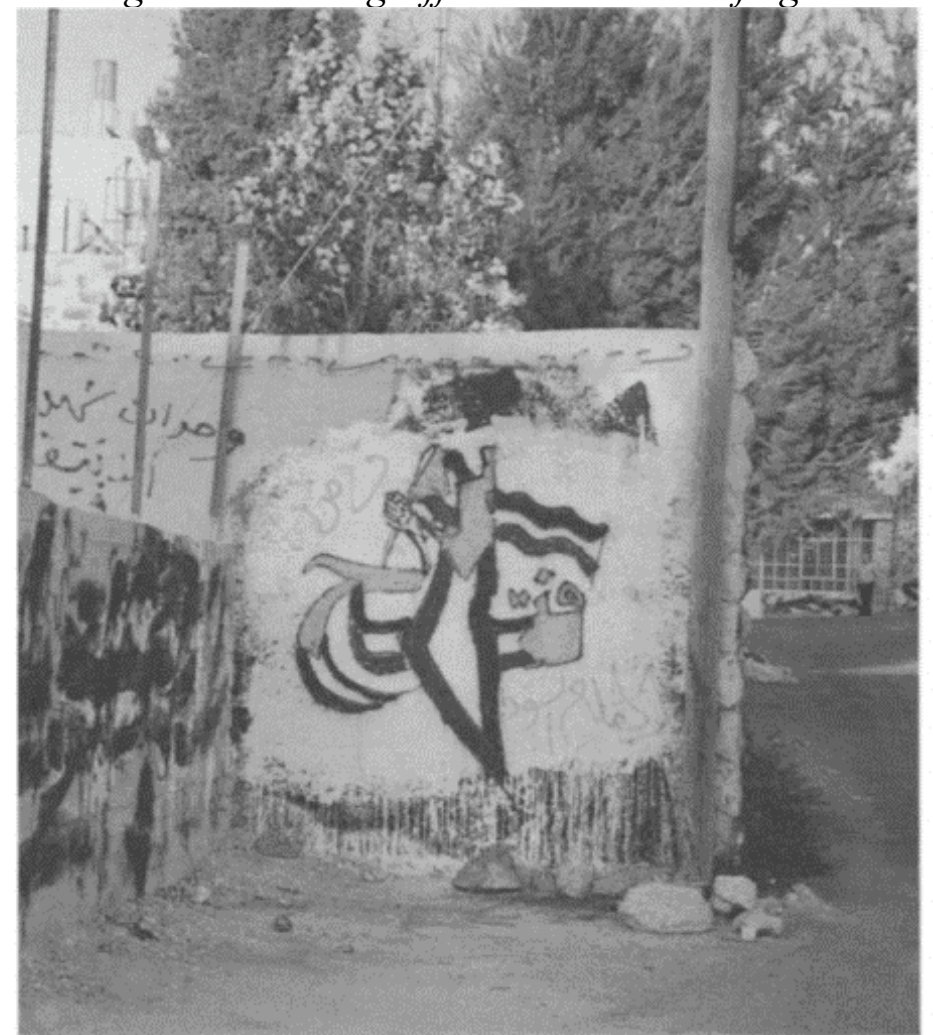

Image source: Peteet, J. (1996) The writing on the walls: the graffiti of the intifada. Cultural Anthropology, (2), 141. 
Figure 5: Wall mural inside a refugee camp, Bethlehem, 2009.

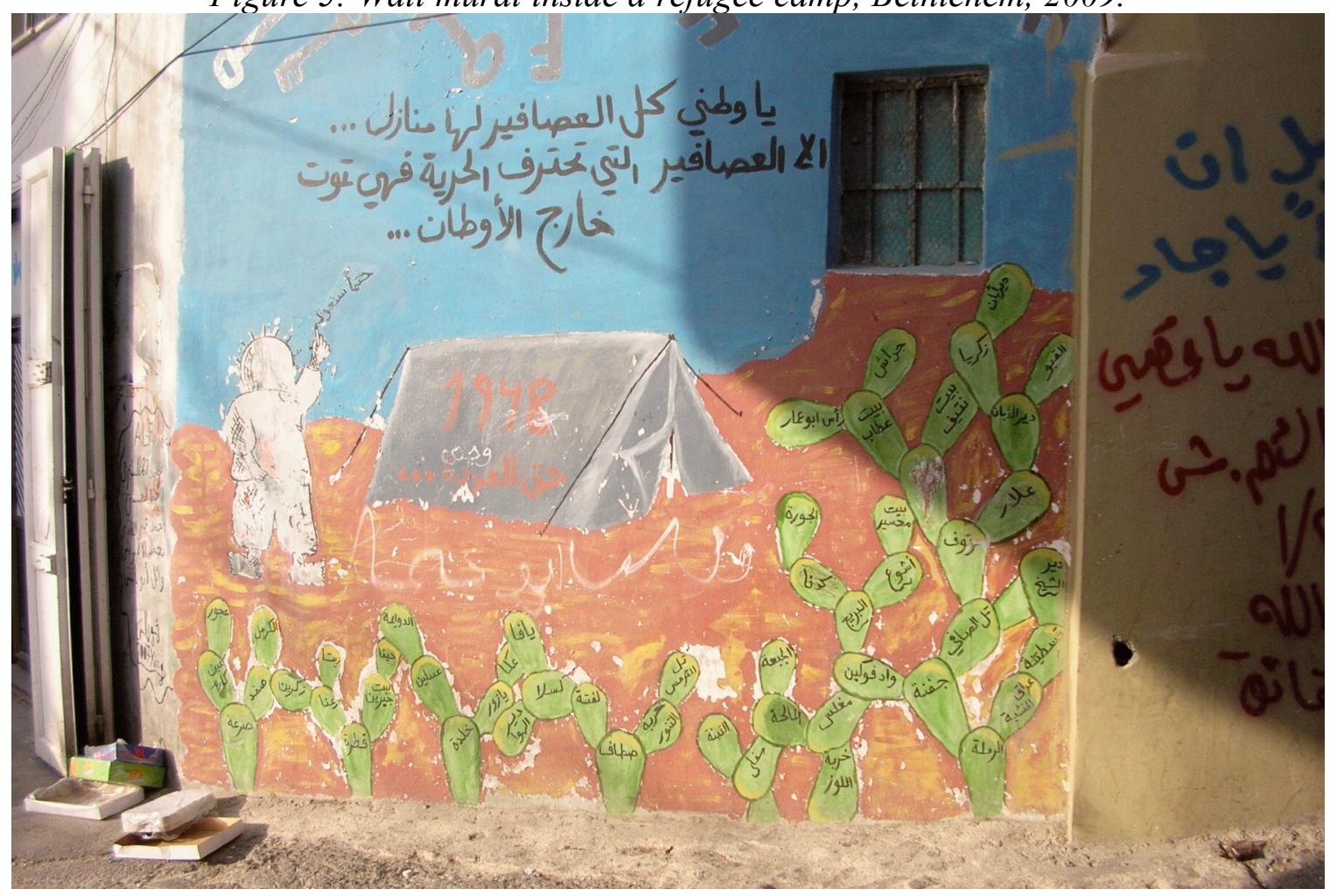

Source: Author's personal archive 


\section{APPENDIX C \\ CONTEMPORARY IMAGES OF APARTHEID}

WALL GRAFFITI

Figure 6: Political and religious references, Bethlehem, 2009

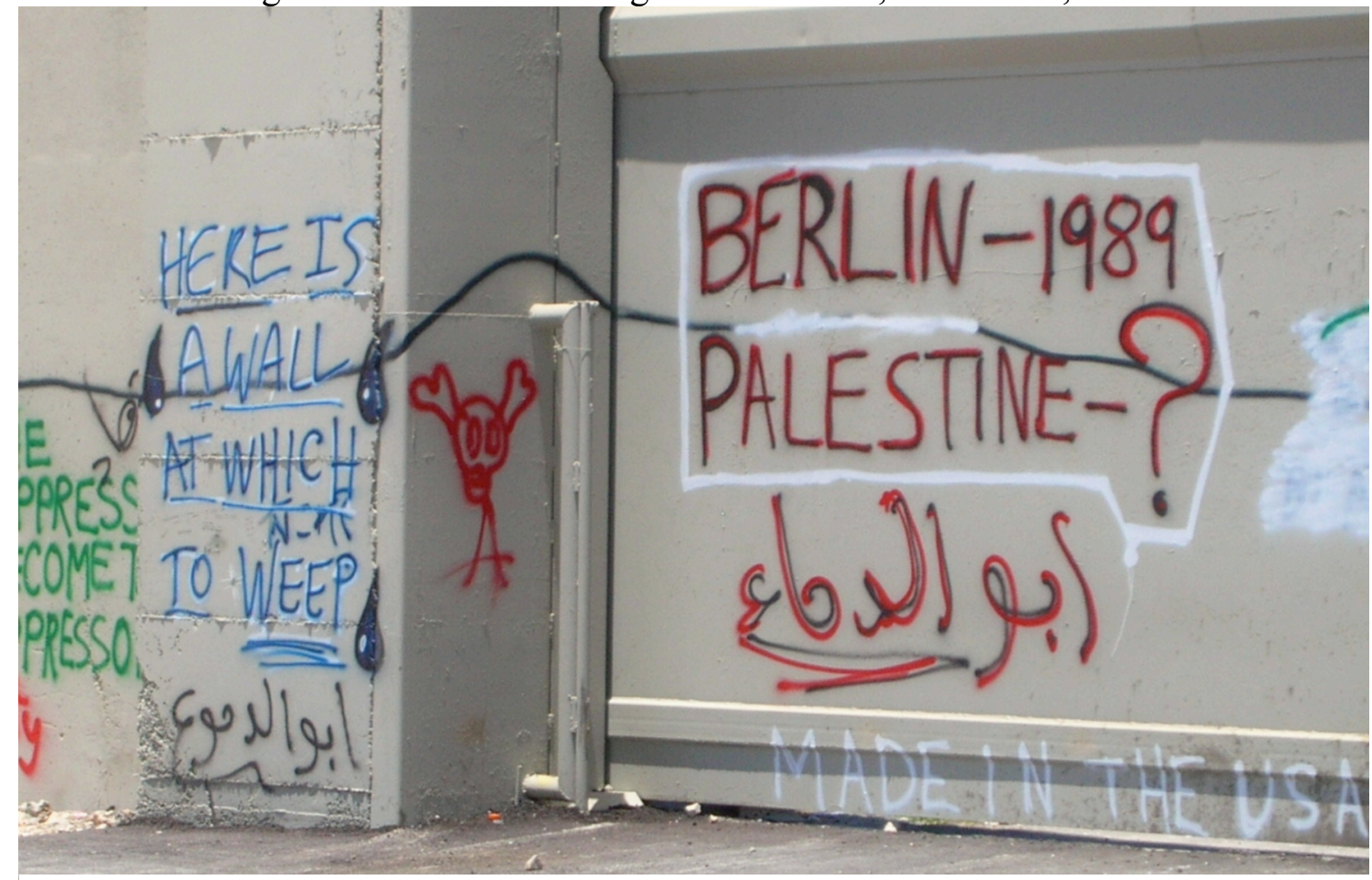

Source: Author's personal archive 
Figure 7: Code switching, Bethlehem, 2009

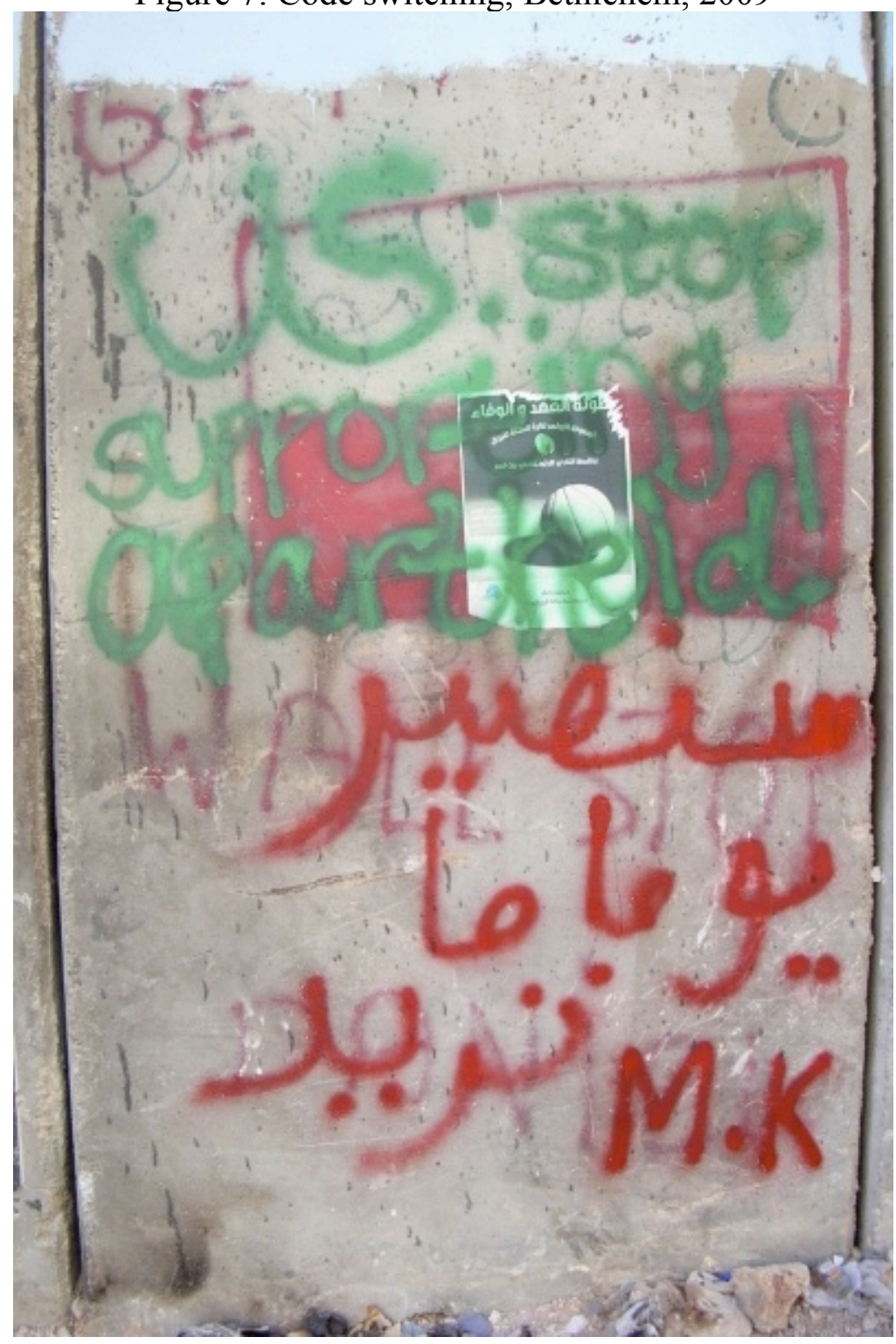

Source: Author's personal archive 
Figure 8: Palimpsest

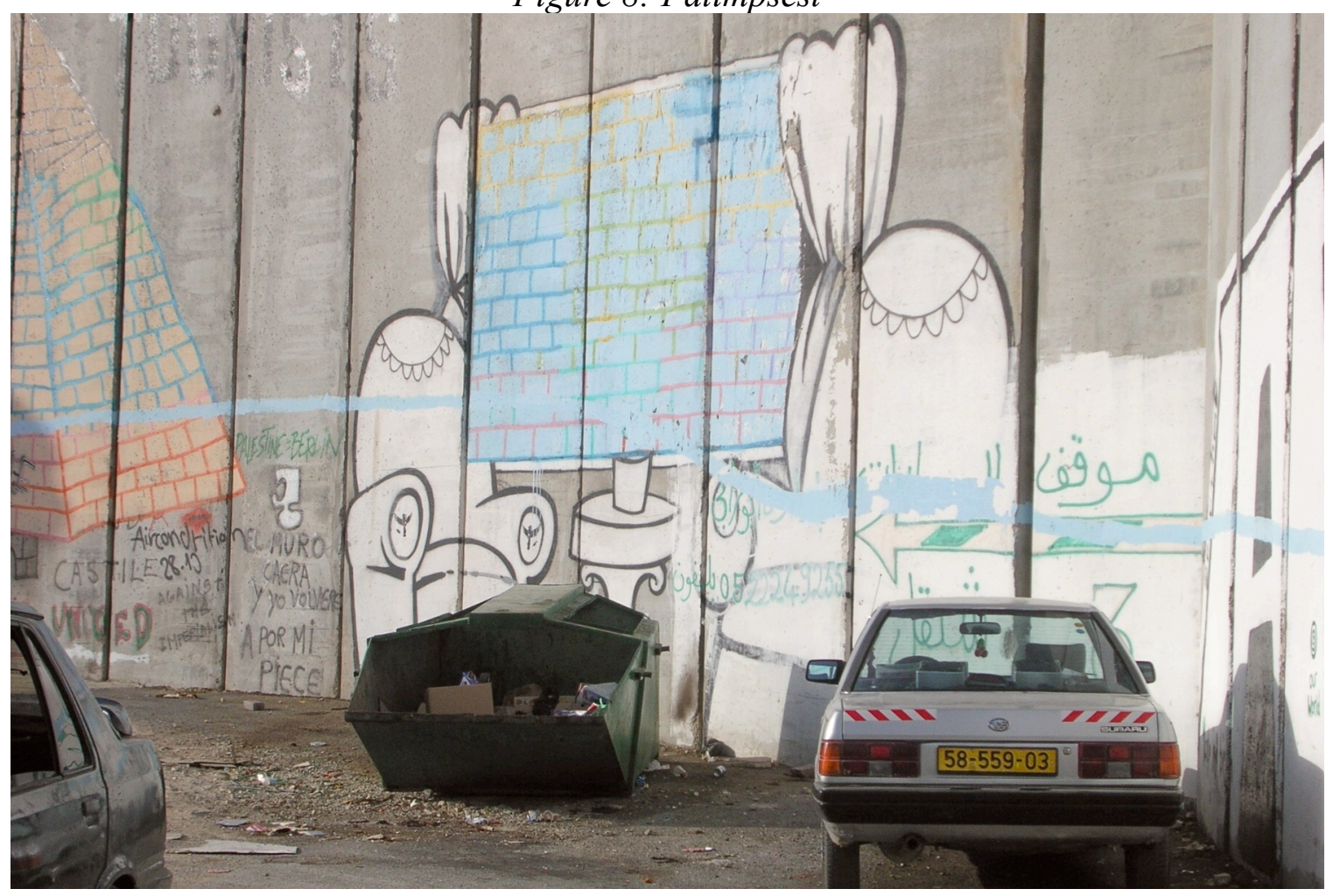

Source: Author's personal archive 